Liping Wang · Eric J. Essene · Youxue Zhang

\title{
Mineral inclusions in pyrope crystals from Garnet Ridge, Arizona, USA: implications for processes in the upper mantle
}

Received: 20 December 1997 / Accepted: 15 October 1998

\begin{abstract}
Mineral inclusions in pyrope crystals from Garnet Ridge in the Navajo Volcanic Field on the Colorado Plateau are investigated in this study with emphasis on the oxide minerals. Each pyrope crystal is roughly uniform in composition except for diffusion halos surrounding some inclusions. The pyrope crystals have near constant $\mathrm{Ca}: \mathrm{Fe}: \mathrm{Mg}$ ratios, 0.3 to $5.7 \mathrm{wt} \%$ $\mathrm{Cr}_{2} \mathrm{O}_{3}$, and 20 to $220 \mathrm{ppm} \mathrm{H}_{2} \mathrm{O}$. Thermobarometric calculations show that pyrope crystals with different $\mathrm{Cr}$ contents formed at different depths ranging from $50 \mathrm{~km}$ (where $T \approx 600{ }^{\circ} \mathrm{C}$ and $P=15 \mathrm{kbar}$ ) to $95 \mathrm{~km}$ (where $T \approx 800{ }^{\circ} \mathrm{C}$ and $P=30$ kbar) along the local geotherm. In addition to previously reported inclusions of rutile, spinel and ilmenite, we discovered crichtonite series minerals $\left(\mathrm{AM}_{21} \mathrm{O}_{38}\right.$, where $A=\mathrm{Sr}, \mathrm{Ca}, \mathrm{Ba}$ and LREE, and $M$ mainly includes $\mathrm{Ti}, \mathrm{Cr}, \mathrm{Fe}$ and $\mathrm{Zr}$ ), srilankite $\left(\mathrm{ZrTi}_{2} \mathrm{O}_{6}\right)$, and a new oxide mineral, carmichaelite $\left(\mathrm{MO}_{2-\mathrm{x}}(\mathrm{OH})_{\mathrm{x}}\right.$, where $M=\mathrm{Ti}, \mathrm{Cr}, \mathrm{Fe}, \mathrm{Al}$ and $\left.\mathrm{Mg}\right)$. Relatively large rutile inclusions contain a significant $\mathrm{Nb}$ (up to $2.7 \mathrm{wt} \% \mathrm{Nb}_{2} \mathrm{O}_{5}$ ), $\mathrm{Cr}$ (up to $\sim 6 \mathrm{wt} \% \mathrm{Cr}_{2} \mathrm{O}_{3}$ ), and $\mathrm{OH}$ (up to $\sim 0.9 \mathrm{wt} \% \mathrm{H}_{2} \mathrm{O}$ ). The $\mathrm{Cr}$ and $\mathrm{OH}$ contents of rutile inclusions are positively related to those of pyrope hosts, respectively. Needle- and blade-like oxide inclusions are commonly preferentially oriented. Composite inclusions consisting mainly of carbonate, amphibole, phlogopite, chlorapatite, spinel and rutile are interpreted to have crystallized from trapped fluid/melt. These minerals in composite inclusions commonly occur at the boundaries between garnet host and large silicate inclusions of peridotitic origin, such as olivine, enstatite and diopside. The Ti-rich oxide minerals may constitute a potential repository for high field strength elements (HFSE), large ion lithophile elements and light rare earth elements (LREE) in the upper mantle. The com-
\end{abstract}

L. Wang $(\bowtie) \cdot$ E.J. Essene $\cdot$ Y. Zhang

Department of Geological Sciences, University of Michigan, Ann Arbor, MI 48109, USA;

Fax: 734-763-4690; E-mail: liping@umich.edu

Editorial responsibility: I.S.E. Carmichael posite and exotic oxide inclusions strongly suggest an episode of metasomatism in the depleted upper mantle beneath the Colorado Plateau, contemporaneous with the formation of pyrope crystals. Our observations show that mantle metasomatism may deplete HFSE in metasomatic fluids/melts. Such fluids/melts may subsequently contribute substantial trace elements to island arc basalts, providing a possible mechanism for HFSE depletion in these rocks.

\section{Introduction}

The eruption of Colorado Plateau ultramafic diatremes 25-32 Ma ago (Watson 1967) in the Navajo Volcanic Field brought up materials from the upper mantle as xenoliths and xenocrysts. The abundant discrete pyrope crystals with red or purple color are one of such materials and may represent the deepest mantle sampled by these diatremes. Hence, a thorough understanding of these garnets is essential to the study of the composition and the evolution of the upper mantle beneath the Colorado Plateau, as well as the genesis of these diatremes.

There has been much effort to characterize the pyrope crystals, their associated mineral inclusions, and mantle xenoliths from these diatremes (O'Hara and Mercy 1966; McGetchin and Silver 1970, 1972; McGetchin et al. 1970; McGetchin and Besancon 1973; Helmstaedt and Doig 1975; Mercier 1976; Smith and Levy 1976; Hunter and Smith 1981; Roden 1981; Smith 1979, 1987, 1995; Roden et al. 1990; Griffin and Ryan 1995). However, the origin of the pyrope crystals remains controversial. Three hypotheses regarding the genesis of garnets have been proposed. The first is that they were disaggregated from lithospheric garnet peridotite (McGetchin and Silver 1970; Smith and Levy 1976; Smith 1979). The second is that they were derived from a subducted Franciscan oceanic slab, termed "meta-ophiolite" and emplaced in Cenozoic time (Helmstaedt and Doig 1975; Mercier 1976; Helmstaedt and Schulze 1979). Thirdly, 
Hunter and Smith (1981) proposed that the pyrope crystals formed from metamorphosed hydrated oceanic lithosphere, subducted in Precambrian time. Smith (1987) reported composite inclusions, which may represent crystallized trapped melt droplets. Previous studies have been concentrated on the pyrope hosts and silicate and carbonate inclusions. In this paper we report the results of a comprehensive study of minerals included in pyrope crystals with emphasis on the oxide inclusions, which may have very important implications for the mantle processes, but have received minimal study.

\section{Sample preparation and analytical procedures}

The pyrope crystals investigated in this work are from Garnet Ridge, Arizona, one of seven known localities of ultramafic diatreme on the Colorado Plateau. They were collected from surface concentrates, and most are $5-10 \mathrm{~mm}$ in diameter with red or purple color. The pyrope crystals were first polished to obtain two parallel surfaces and then examined using an optical microscope. All mineral inclusions but one (Di-3 in GRPy-8) are completely enclosed in pyrope, and in no case are they associated with cracks extending to the edge of the host. The crystals were polished to bring individual inclusions to the surface. These wafers were then examined using back-scattered electron imaging (BSE) and X-ray energy dispersive analytical system (EDS) on a Hitachi S-570 scanning electron microscope (SEM).

Analyses of pyrope crystals and inclusions were carried out on a four-spectrometer Cameca Camebax electron microprobe (EMP) using an acceleration voltage of $15 \mathrm{kV}$ and a focused beam with a current of $10 \mathrm{nA}$. Counting times of $30 \mathrm{~s}$ or total counts of 40,000 were used for all major elements in standards and unknowns. The analytical data were corrected using the Cameca PAP program. Analyses of $\mathrm{V}$ for oxide inclusions were corrected for the Ti $K_{\beta}$ contribution to the $\mathrm{V} K_{\alpha}$ peak using synthetic standards of $\mathrm{TiO}_{2}$ and $\mathrm{MgTiO}_{3}$, with the LIF spectrometer crystal. The V concentration of an unknown sample was obtained by subtracting $0.0035^{*} \mathrm{Ti}$ wt $\%$ from the $\mathrm{V}$ content of unknowns.

Several mineral inclusions were extracted from host and examined using X-ray diffraction techniques for the positive identification (Gandofi camera), or to characterize a new mineral (single-crystal X-ray study).

\section{Paragenesis and composition}

Pyrope hosts and overall textures of inclusions

The divalent cations in pyrope from Garnet Ridge are relatively uniform and are similar to those previously reported with $\mathrm{Ca}: \mathrm{Fe}: \mathrm{Mg} \approx 13: 16: 71$ (Table 1; McGetchin and Silver 1970; Smith and Levy 1976; Hunter and Smith 1981). The $\mathrm{Cr}_{2} \mathrm{O}_{3}$ concentration varies from $\sim 0.3$ to $\sim 5.7 \mathrm{wt} \%$, with $\mathrm{Cr} \#=100 * \mathrm{Cr} /(\mathrm{Cr}+\mathrm{Al})$ ranging from 0.8 to 16 , and the $\mathrm{TiO}_{2}$ contents are less than $0.2 \mathrm{wt} \%$. These garnets are more pyropic than garnet in spinel lherzolite from the Green Knob diatremes (Ca:Fe:Mg = 13:26:62, Smith and Levy 1976), and similar to those from garnet lherzolite in the Thumb minette (Ehrenberg 1979). The concentration of hydrous component $(\mathrm{OH})$ in some pyrope hosts has been determined by infrared (IR) spectroscopy following the procedure of Wang et al. (1996), using the calibration of Bell et al. (1995). It ranges from 20 to $220 \mathrm{ppm} \mathrm{H}_{2} \mathrm{O}$ (Table 1), and is consistent with the results of Bell (1993).

Many mineral inclusions have been identified in pyrope crystals from the Four Corners area (McGetchin and Silver 1970; McGetchin et al. 1970; McGetchin and Besancon 1973; Smith and Levy 1976; Hunter and Smith 1981; Smith 1987). These include oxides, silicates, carbonates, sulfides, sulfates and phosphates (Table 2). In addition to previously recognized inclusions, we discovered a new mineral (carmichaelite), crichtonite series minerals, srilankite, siderite and barite.

The inclusions can be classified according to textures as follows (Fig. 1):

I. Ellipsoidal or round monomineralic inclusions, including large olivine, diopside, enstatite or spinel grains that are usually surrounded by a radiating array of fractures or a birefringent halo (except for spinel) (Fig. 1a). Some of these inclusions are partially replaced by mineral assemblages that may have resulted from mineral-fluid/melt interaction prior to trapping in the pyrope hosts (Fig. 1b, c).

II. Needle-, rod- or blade-like oxide inclusions that are commonly oriented parallel to certain crystallographic directions of the pyrope host, including rutile, minerals of crichtonite series, ilmenite, srilankite and carmichaelite (Fig. 1d; and later Figs. 3, 4). Olivine, magnesite and dolomite may also adopt this mode of texture (Fig. 1e). Rarely Ti-clinohumite and Ti-chondrodite were found replacing needle or tabular olivine (Fig. 1f). Commonly these inclusions are coexisting and in alignment.

III. Composite inclusions containing carbonate and hydrous minerals, which are probably solidified fluid/ melt inclusions (Fig. 1g). These inclusions are randomly distributed in the pyrope hosts. They are generally round, but may have a negative pyrope crystal habit (i.e., cubic or octahedron), a characteristic of primary fluid/melt inclusions. These inclusions mainly consist of carbonate, amphibole, phlogopite, kinoshitalite, chlorapatite, spinel, sulfides and less commonly rutile. They may be surrounded by rutile-carbonate clusters.

IV. The same minerals as those in the composite inclusions, which occur at the boundary between large inclusions of olivine, diopside or enstatite and their pyrope hosts (Fig. 1h).

V. Inclusions associated with complex compositional zonation in pyrope, including amphibole, chromite, chromian diopside (Fig. 6c, d), and rarely chlorite and barite.

Inclusions of olivine, diopside and enstatite

All three minerals are present as texture-I inclusions in each of two pyrope crystals (GRPy-8 and GRPy-15). 


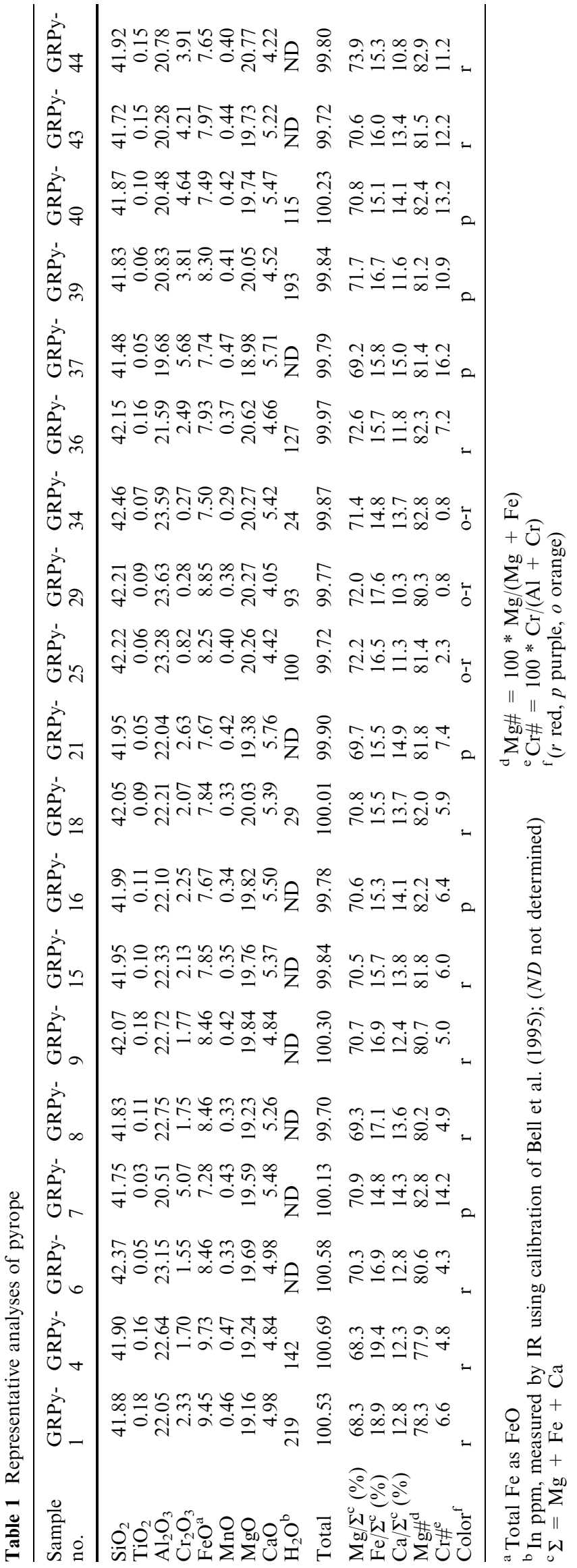

The compositions of representative inclusions from these two samples are presented in Table 3, along with size estimates of each inclusion. All data are averages of two or more analyses from the central parts of each inclusion. Five olivine inclusions were analyzed in sample GRPy-15. The composition of each crystal is roughly uniform but the Mg\# of olivine decreases with increasing size (Fig. 2a). Profile analyses were carried out for the pyrope host near two olivine inclusions (Ol-1 and Ol2 in GRPy-15, Fig. 2b), and are used to infer the original olivine compositions.

Inclusions of olivine, diopside and enstatite (texture I) in many other pyrope crystals have also been analyzed. The results are consistent with previous studies (McGetchin and Silver 1970; Hunter and Smith 1981; Smith and Wilson 1985; Smith and Barron 1991). These include: (1) all three minerals are $\mathrm{Mg}$-rich $(\mathrm{Mg} \# \geq 93)$; (2) clinopyroxene has a $\mathrm{Ca} /(\mathrm{Mg}+\mathrm{Ca}+\mathrm{Fe})$ ratio ranging from 0.47 to 0.50 , and orthopyroxene is relatively low in $\mathrm{Al}_{2} \mathrm{O}_{3}(<1.6 \mathrm{wt} \%)$; (3) inclusions and pyrope hosts are generally zoned near mutual contacts (i.e., Fig. 2b) except for olivine; (4) the Mg\# of olivine inclusions in the same pyrope host depends on the size of inclusion (i.e., Fig. 2a).

\section{Ti-clinohumite and Ti-chondrodite}

Ti-clinohumite and Ti-chondrodite are yellowish brown in garnet in transmitted light. They coexist with rutile, olivine (Fig. 1b, f) or enstatite, and are commonly complexly intergrown. Figure $1 \mathrm{~b}$ shows clearly a reaction texture among coexisting mineral inclusions, including olivine, rutile, Ti-clinohumite and Ti-chondrodite. The compositions of the two minerals (Table 4) are very similar to those from Moses Rock (McGetchin et al. 1970) and Buell Park (Aoki et al. 1976). The Garnet Ridge humites are almost F-free.

\section{Crichtonite series}

Minerals of crichtonite series have the general formula $\mathrm{AM}_{21} \mathrm{O}_{38}$, where $A$ is a large radius cation $(\mathrm{Sr}, \mathrm{Pb}, \mathrm{REE}$, $\mathrm{U}, \mathrm{Ca}, \mathrm{Na}, \mathrm{K}, \mathrm{Ba}$ ) occupying one of 39 anion sites (12coordinated), and $M$ are smaller cations ( $\mathrm{Ti}, \mathrm{Fe}, \mathrm{Cr}, \mathrm{Al}$, $\mathrm{Zr}, \mathrm{Mg}$ ) occupying 19 octahedral and two tetrahedral interstices between stacked anion layers. Minerals in the series are named according to the dominant A-site cation: $\mathrm{Sr}$, crichtonite; $\mathrm{Ca}$, loveringite; $\mathrm{Na}$, landauite; $\mathrm{Pb}$, senaite; REE, davidite; $\mathrm{Ba}$, lindsleyite; and $\mathrm{K}$, mathiasite (Rouse and Peacor 1968; Grey et al. 1976; Gatehouse et al. 1978; Haggerty et al. 1983). Although they typically occur as accessory minerals in mafic and alkalic rocks (Grey et al. 1976; Campbell and Kelly 1978; Gatehouse et al. 1978; Lorand et al. 1987), members of this series originating from the upper mantle have been reported in metasomatized mantle xenoliths or heavy mineral concentrates from kimberlites (Haggerty 1975, 
Table 2 Mineral inclusions in pyrope

\begin{tabular}{ll}
\hline Silicates & Oxides \\
Olivine (Ol) & Crichtonite (Ctn) \\
Diopside (Di) & Loveringite (Lvn) \\
Enstatite (En) & Srilankite (Slk) \\
Amphibole (Amp) & Carmichaelite (Cml) \\
Phlogopite (Phl) & Rutile (Rt) \\
Kinoshitalite (Ksh) & Spinel (Spl) \\
Ti-clinohumite (TiChu) & Ilmenite (Ilm) \\
Ti-chondrodite (TiChn) & \\
Chlorite (Chl) & Carbonates \\
& Magnesite (Mgs) \\
Phosphate, sulfide, sulfate & Dolomite (Dol) \\
Chlorapatite (ClAp) & Ca-carbonate (Cac) \\
Pyrite (Py) & Siderite (Sd) \\
Barite (Brt) & \\
\hline
\end{tabular}

1983, 1991a; Erlank and Rickard 1977; Jones et al. 1982; Zhou et al. 1984; Haggerty et al. 1986). Crichtonite series minerals from the mantle association are predominantly lindsleyite and mathiasite (LIMA), which contain significant $\mathrm{Sr}, \mathrm{Ca}, \mathrm{Na}$ and $\mathrm{REE}$ in the A-site (Jones et al. 1982; Haggerty 1991a). Possible crichtonite inclusions in garnet from kimberlite and lamprophyre have been reported (Varlamov et al. 1996), but the compositions do not allow conclusive identification.

In contrast to previous studies which have not identified crichtonite series minerals as inclusions in pyrope crystals from Garnet Ridge, we found that they are abundant. They were identified by microprobe analysis and reflectivity (rutile $>$ crichtonite $>$ srilankite $\approx$ carmichaelite $>$ ilmenite $>$ spinel). An X-ray study
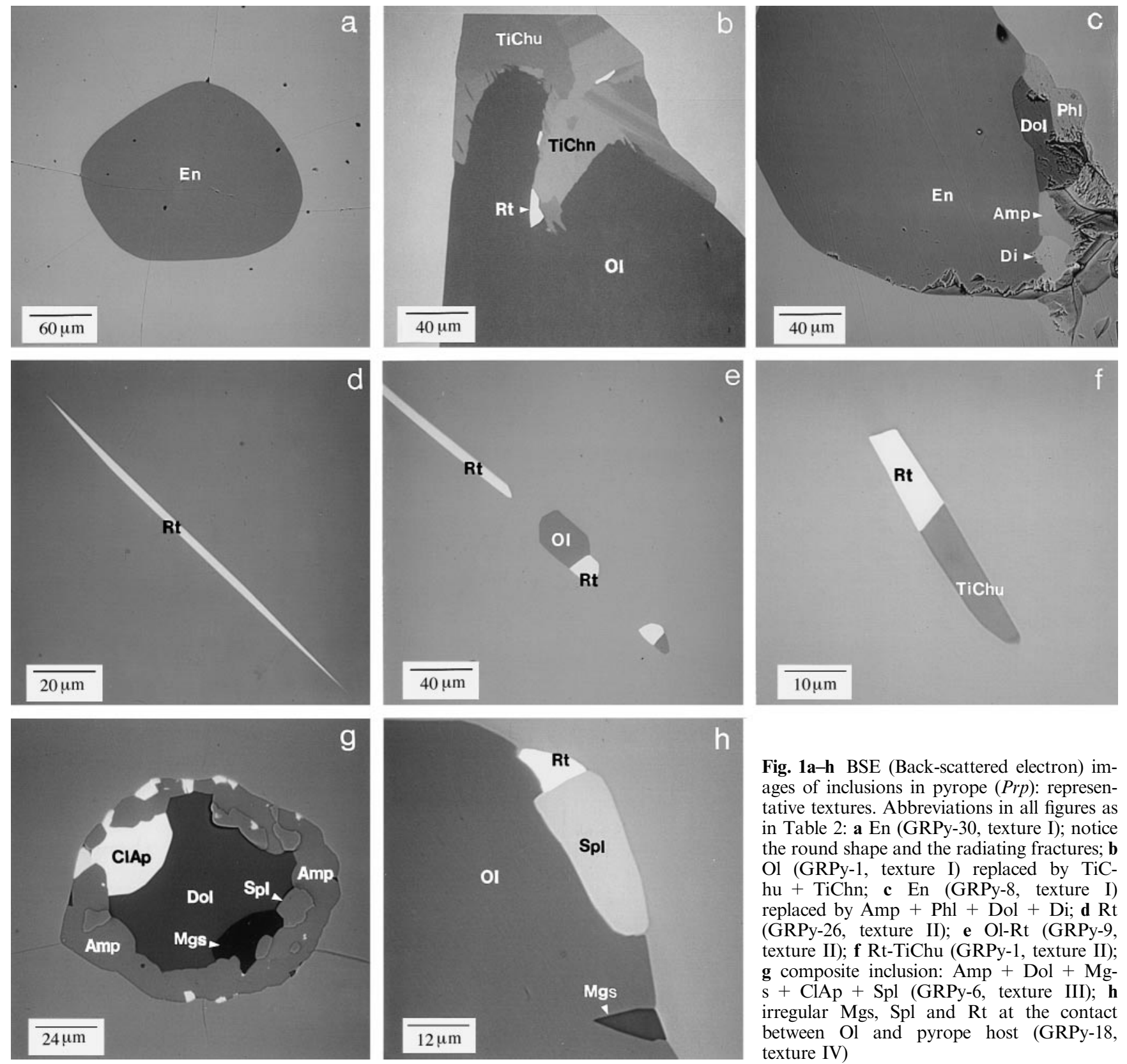

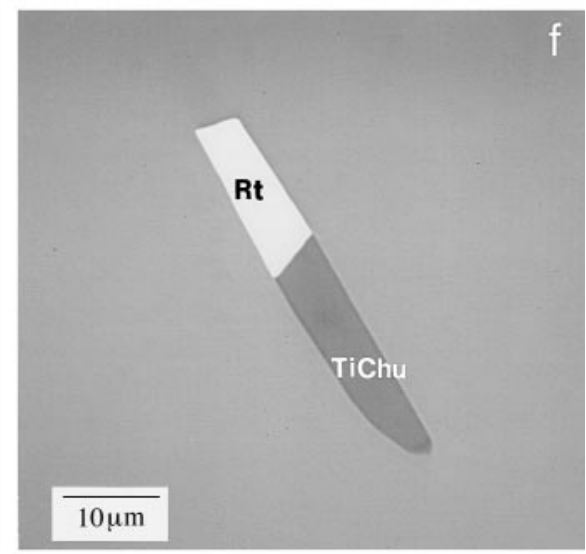

Fig. 1a-h BSE (Back-scattered electron) images of inclusions in pyrope (Prp): representative textures. Abbreviations in all figures as in Table 2: a En (GRPy-30, texture I); notice the round shape and the radiating fractures; $\mathbf{b}$ Ol (GRPy-1, texture I) replaced by $\mathrm{TiC}$ hu + TiChn; c En (GRPy-8, texture I) replaced by Amp $+\mathrm{Phl}+\mathrm{Dol}+\mathrm{Di} ; \mathbf{d} \mathrm{Rt}$ (GRPy-26, texture II); e Ol-Rt (GRPy-9, texture II); f Rt-TiChu (GRPy-1, texture II); g composite inclusion: $\mathrm{Amp}+\mathrm{Dol}+\mathrm{Mg}-$ $\mathrm{s}+\mathrm{ClAp}+\mathrm{Spl}$ (GRPy-6, texture III); h irregular $\mathrm{Mgs}$, $\mathrm{Spl}$ and $\mathrm{Rt}$ at the contact between $\mathrm{Ol}$ and pyrope host (GRPy-18, texture IV) 
Table 3 Representative analyses of olivine, diopside and enstatite inclusions

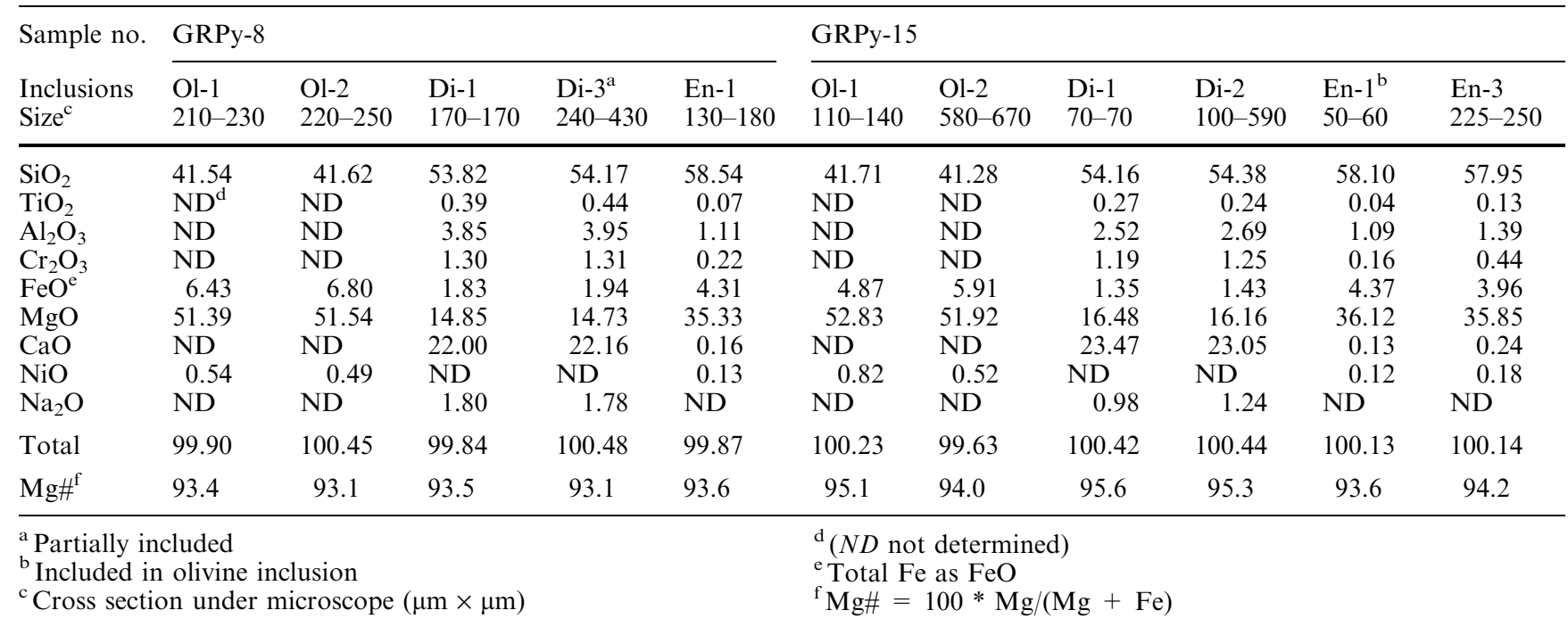
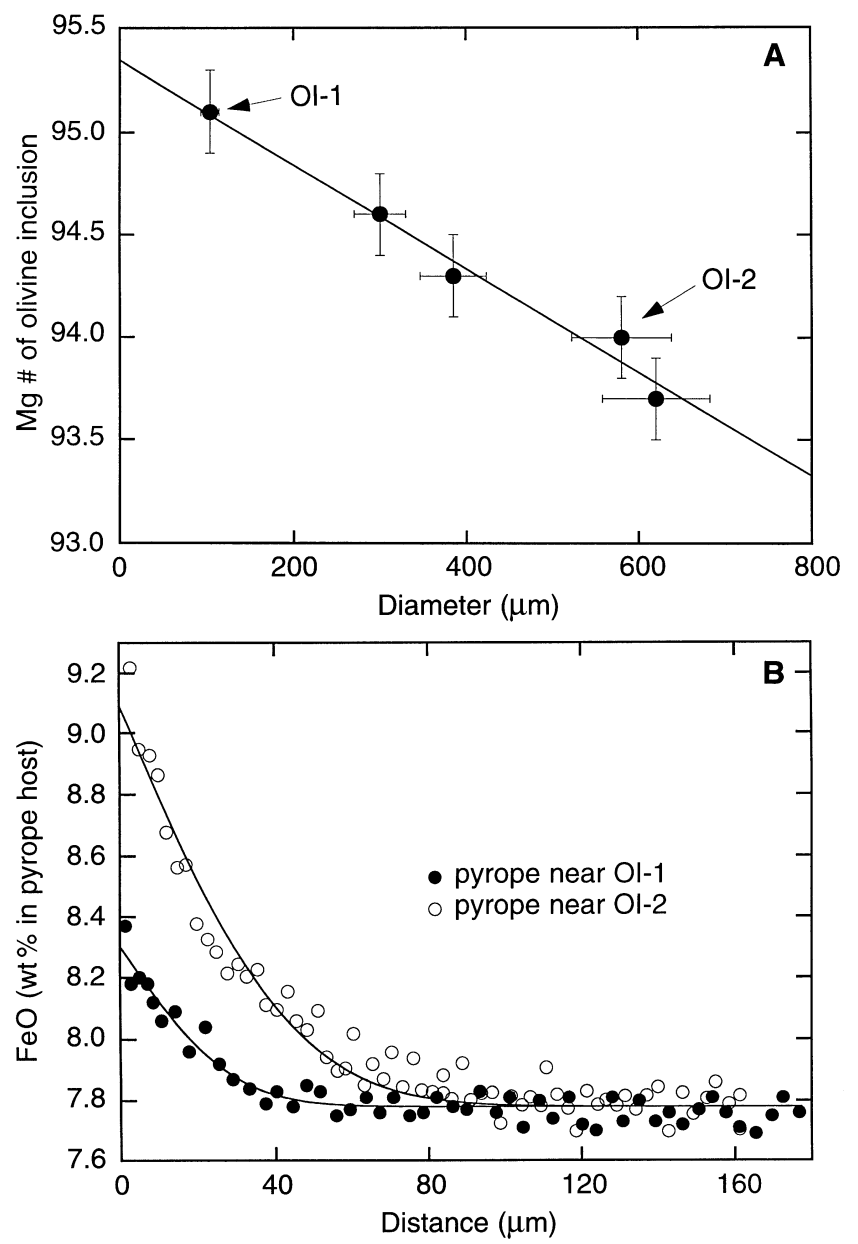

Fig. 2 A The relationship between $\mathrm{Mg} \#=100 * \mathrm{Mg} /(\mathrm{Mg}+\mathrm{Fe})$ of olivine inclusion and its size in sample GRPy-15. Solid line is a linear fit. B FeO profiles in pyrope host (GRPy-15) near two olivine inclusions (Ol-1 and $\mathrm{Ol}-2$ ). The error in $\mathrm{FeO}$ analysis is typically $0.1 \mathrm{wt} \%(1 \sigma)$. The boundaries between olivine and pyrope are at distance of zero. The solid lines are the fits of by error function using Gandofi camera on a separated inclusion $\left(50 \times 50 \times 30 \mu^{3}\right)$ yielded a diffraction pattern matched by that of crichtonite. They commonly occur as preferentially oriented needle or tabular grains, and may contact rutile, ilmenite and srilankite (Fig. 3a-d).

The compositions of crichtonite series minerals are uniform in a single garnet host, but variable among different garnet crystals (Table 5). The A-site cations are mainly $\mathrm{Sr}, \mathrm{Ca}, \mathrm{Ba}, \mathrm{La}$ and $\mathrm{Ce}$. Determination of other rare earth elements (REE) has been attempted, but their concentration is generally below the microprobe detection limit $(\sim 0.2 \mathrm{wt} \%)$. The M-site cations mainly include $\mathrm{Ti}, \mathrm{Cr}$ and $\mathrm{Fe}$, and significant $\mathrm{Zr}, \mathrm{Al}$ and $\mathrm{Mg}$. Crichtonite series minerals are variable in $\mathrm{TiO}_{2}$ (ranging from $\sim 53$ to $\sim 69 \mathrm{wt} \%$ ) and $\mathrm{Cr}_{2} \mathrm{O}_{3}$ (ranging from $\sim 1.2$ to $\sim 21 \mathrm{wt} \%$ ). The $\mathrm{TiO}_{2}$ and $\mathrm{Cr}_{2} \mathrm{O}_{3}$ contents are roughly negatively correlated, with a sum of $71.0 \pm 2.4 \mathrm{wt} \%$. The $\mathrm{Cr}_{2} \mathrm{O}_{3}$ content of crichtonite is positively related to that of its garnet host. The distribution coefficient $\left(K_{\mathrm{D}}\right)$ of $\mathrm{Cr} / \mathrm{Al}$ between crichtonite and its pyrope host is calculated to be $49 \pm 14$ ( $1 \sigma$ uncertainty). These crichtonite series inclusions are enriched in $\mathrm{ZrO}_{2}$ with a Ti/Zr ratio of $13.7 \pm 3.8$, a value much smaller than that of primitive mantle (115; McDonough and Sun 1995). The average $\mathrm{Hf} / \mathrm{Zr}$ ratio is $0.036 \pm 0.013$, not much greater than the primitive mantle value $(0.027$; McDonough and Sun 1995).

Compared with crichtonite series minerals from metasomatic mantle associations (Erlank and Rickard 1977; Jones et al. 1982; Haggerty et al. 1983; Haggerty 1983, 1987, 1991a), the minerals from Garnet Ridge differ in terms of the A-site cation compositions. Furthermore, two crichtonite grains in sample GRPy-43 record the highest $\mathrm{Cr}_{2} \mathrm{O}_{3}$ concentration $(\sim 21 \mathrm{wt} \%)$ ever reported, and those from GRPy-34 have a higher $\mathrm{TiO}_{2}$ concentration than other reported crichtonite series minerals from the mantle. 
Table 4 Analyses of Ti-clinohumite and Ti-chondrodite

\begin{tabular}{|c|c|c|c|c|c|c|}
\hline \multirow{2}{*}{$\begin{array}{l}\text { Sample no. } \\
\text { Inclusions }\end{array}$} & \multicolumn{3}{|l|}{ GRPy-1 } & \multicolumn{2}{|l|}{ GRPy-4 } & \multirow{2}{*}{$\begin{array}{l}\text { GRPy-9 } \\
\text { TiChu-1 }\end{array}$} \\
\hline & TiChu-1 & TiChn-1 & TiChu-2 & TiChu-1 & TiChn-1 & \\
\hline $\mathrm{SiO}_{2}$ & 36.81 & 32.94 & 37.84 & 36.89 & 33.49 & 36.83 \\
\hline $\mathrm{MgO}$ & 48.19 & 45.40 & 50.17 & 48.87 & 46.80 & 49.09 \\
\hline $\mathrm{Al}_{2} \mathrm{O}_{3}$ & 0.01 & 0.02 & 0.02 & 0.02 & 0.02 & 0.03 \\
\hline $\mathrm{CaO}$ & 0.02 & 0.01 & 0.03 & 0.02 & 0.02 & 0.02 \\
\hline $\mathrm{TiO}_{2}$ & 5.52 & 9.61 & 5.80 & 5.37 & 9.34 & 6.04 \\
\hline $\mathrm{Cr}_{2} \mathrm{O}_{3}$ & 0.08 & 0.11 & 0.15 & 0.05 & 0.09 & 0.08 \\
\hline $\mathrm{MnO}$ & 0.07 & 0.07 & 0.03 & 0.08 & 0.08 & 0.03 \\
\hline $\mathrm{NiO}$ & 0.30 & 0.27 & 0.81 & 0.33 & 0.30 & 0.67 \\
\hline $\mathrm{FeO}^{\mathrm{a}}$ & 6.46 & 6.73 & 4.95 & 6.41 & 6.64 & 4.80 \\
\hline $\mathrm{F}$ & $<0.01$ & $<0.01$ & $<0.01$ & $<0.01$ & $<0.01$ & $<0.01$ \\
\hline $\mathrm{H}_{2} \mathrm{O}^{\mathrm{b}}$ & 1.81 & 3.18 & 1.81 & 1.65 & 3.19 & 1.52 \\
\hline Total & 99.27 & 98.33 & 101.61 & 99.68 & 99.97 & 99.10 \\
\hline \multicolumn{7}{|c|}{ Formulae normalized to $4 \mathrm{Si}(\mathrm{TiChu})$ and $2 \mathrm{Si}$ (TiChn) } \\
\hline $\mathrm{Si}$ & 4.000 & 2.000 & 4.000 & 4.000 & 2.000 & 4.000 \\
\hline $\mathrm{Mg}$ & 7.808 & 4.110 & 7.905 & 7.899 & 4.167 & 7.948 \\
\hline $\mathrm{Al}$ & 0.001 & 0.001 & 0.003 & 0.002 & 0.001 & 0.004 \\
\hline $\mathrm{Ca}$ & 0.003 & 0.001 & 0.004 & 0.002 & 0.001 & 0.002 \\
\hline $\mathrm{Ti}$ & 0.451 & 0.439 & 0.461 & 0.438 & 0.420 & 0.494 \\
\hline $\mathrm{Cr}$ & 0.007 & 0.005 & 0.012 & 0.005 & 0.004 & 0.007 \\
\hline $\mathrm{Mn}$ & 0.006 & 0.004 & 0.003 & 0.007 & 0.004 & 0.003 \\
\hline $\mathrm{Ni}$ & 0.026 & 0.013 & 0.069 & 0.029 & 0.014 & 0.058 \\
\hline $\mathrm{Fe}^{2+}$ & 0.587 & 0.342 & 0.437 & 0.581 & 0.332 & 0.436 \\
\hline F & 0.000 & 0.000 & 0.000 & 0.000 & 0.000 & 0.000 \\
\hline $\mathrm{OH}^{\mathrm{c}}$ & 1.310 & 1.285 & 1.275 & 1.191 & 1.266 & 1.099 \\
\hline $\mathrm{M} / \mathrm{Si}^{\mathrm{d}}$ & 2.222 & 2.458 & 2.223 & 2.241 & 2.472 & 2.238 \\
\hline
\end{tabular}

Total $\mathrm{Fe}$ as $\mathrm{FeO}$

${ }^{\mathrm{b}}$ From calculated $\mathrm{OH}$

${ }^{\mathrm{c}}$ Calculated from stoichiometry and charge balance

${ }^{\mathrm{d}} M=\mathrm{Mg}+\mathrm{Fe}+\mathrm{Mn}+\mathrm{Ca}+\mathrm{Ni}+\mathrm{Al}+\mathrm{Cr}+\mathrm{Ti}$

\section{Srilankite}

Srilankite $\left(\mathrm{ZrTi}_{2} \mathrm{O}_{6}\right)$, a mineral highly enriched in HFSE, occurs as small euhedral grains $(5-20 \mu \mathrm{m})$ coexisting with rutile, ilmenite, loveringite and carmichaelite (Fig. $4 \mathrm{a}-\mathrm{d}$ ). This is the third known occurrence of srilankite. Willgallis et al. (1983) discovered this mineral in pebbles in the Rakwana region, Sri Lanka. In a second occurrence from the Yagodka lamprophyre pipe in the Tobuk-Khatystyr field, srilankite was found as inclusions in pyrope-almandine garnets (Kostrovitskiy et al. 1993). In common with previous occurrences, srilankite from Garnet Ridge is transparent and with blue internal reflections in transmitted light under crossed polars. In reflected light, it is gray-to-white and anisotropic. Its reflectivity is higher than spinel, but less than rutile. The compositions are quite uniform for different srilankite grains from different pyrope hosts (Table 6). These data are similar to the first occurrence of srilankite (Willgallis et al. 1983), but differ from the composition of the srilankite from Yagodka (Kostrovitskiy et al. 1993), which varies significantly in $\mathrm{Ti}, \mathrm{Zr}$ and $\mathrm{Fe}$ among different grains. The average $\mathrm{Hf} / \mathrm{Zr}$ ratio for Garnet Ridge srilankite is $0.012 \pm 0.003$, also similar to the first occurrence, but much lower than that of primitive mantle (0.027; McDonough and Sun 1995). The elemental exchange coefficient of $\mathrm{Hf} / \mathrm{Zr}$ between coexisting crichtonite series minerals and srilankite has been cal- culated to be $3.1 \pm 1.3$. Hence, at least one of the minerals could cause fractionation of $\mathrm{Hf} / \mathrm{Zr}$ ratio in the mantle.

\section{Rutile}

Needle, blade and rod-like rutile is the most common inclusion in these pyrope crystals. Needle-like rutile is usually regularly spaced and preferentially oriented in

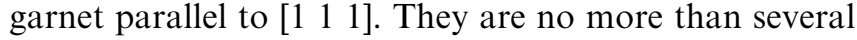
micrometers in thickness, but may be several millimeters in length (Fig. 1d). Blade or rod-like rutile is also preferentially oriented in most cases, but is sometimes randomly distributed. In addition to occurring as single crystals, rutile may also coexist with other oxide minerals, carbonates and needle/rod olivine. Some occur at the boundaries between garnet and other silicate inclusions. Table 7 shows that $\mathrm{TiO}_{2}$ ranges from 91 to $97 \mathrm{wt} \%$, with $\mathrm{Cr}_{2} \mathrm{O}_{3}$ contents from 0.4 to $6 \mathrm{wt} \%$, roughly increasing with the $\mathrm{Cr}_{2} \mathrm{O}_{3}$ concentration of the pyrope host (Fig. 5a). The rutile inclusions are enriched in $\mathrm{Nb}$ as most grains have a $\mathrm{Ti} / \mathrm{Nb}$ ratio much lower than that of primitive mantle (1831: McDonough and Sun 1995). Compared to those from South Africa kimberlite (e.g., Haggerty 1983, 1991a; Schulze 1990; Mitchell 1991), most Garnet Ridge rutiles have lower $\mathrm{Cr}$ and $\mathrm{Nb}$ contents. 
Fig. 3a-d BSE images of crichtonite series and their coexisting minerals: a $\mathrm{Lvn}+\mathrm{Ilm}+\mathrm{Rt}+\mathrm{Slk}$ (GRPy-34); b Lvn + Slk + Rt (GRPy-34); c Ctn + Rt (GRPy-41); d Ctn + Rt (GRPy-43)
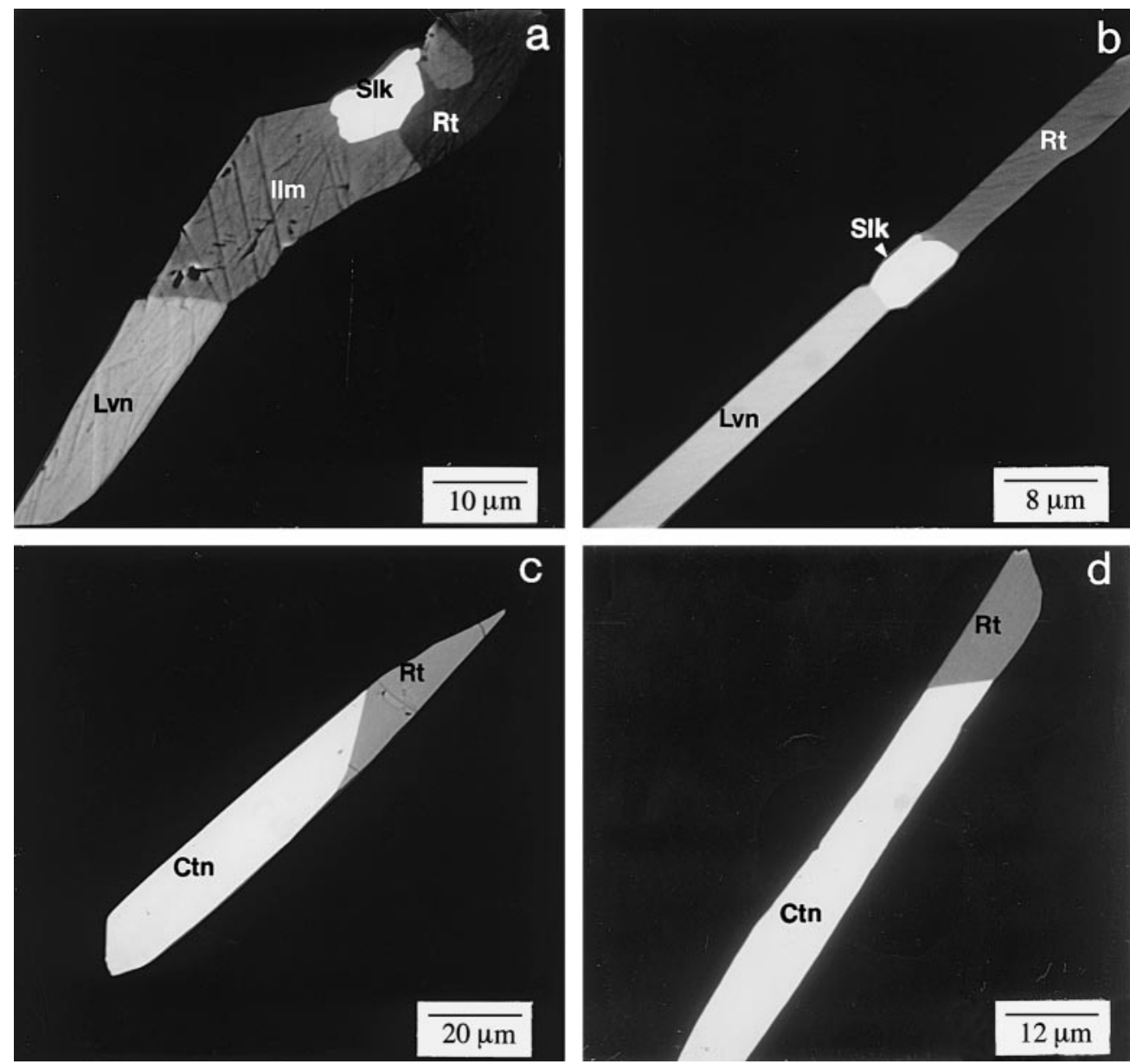

Table 5 Representative analyses of crichtonite series minerals

\begin{tabular}{|c|c|c|c|c|c|c|c|c|c|c|c|}
\hline \multirow{2}{*}{$\begin{array}{l}\text { Sample } \\
\text { Grain no. }\end{array}$} & \multicolumn{3}{|c|}{ GRPy-34 } & \multicolumn{5}{|c|}{ GRPy-40 } & \multicolumn{2}{|c|}{ GRPy-43 } & \multirow{2}{*}{$\begin{array}{l}\text { GRPy-44 } \\
1\end{array}$} \\
\hline & 1 & 2 & 3 & 1 & 2 & 3 & 4 & 5 & 1 & 2 & \\
\hline $\mathrm{TiO}_{2}$ & 68.62 & 68.49 & 65.75 & 52.93 & 52.61 & 52.87 & 53.62 & 52.64 & 55.44 & 52.55 & 62.08 \\
\hline $\mathrm{ZrO}_{2}$ & 4.07 & 3.66 & 6.28 & 2.49 & 2.52 & 2.73 & 2.34 & 2.52 & 4.58 & 4.65 & 5.42 \\
\hline $\mathrm{HfO}_{2}$ & 0.12 & 0.14 & 0.14 & 0.11 & 0.09 & 0.13 & 0.10 & 0.02 & 0.10 & 0.13 & 0.15 \\
\hline $\mathrm{SiO}_{2}$ & 0.07 & 0.06 & 0.08 & 0.02 & 0.01 & 0.02 & 0.03 & 0.43 & 0.04 & 0.04 & 0.03 \\
\hline $\mathrm{Al}_{2} \mathrm{O}_{3}$ & 2.10 & 2.57 & 4.13 & 1.97 & 1.96 & 2.00 & 2.11 & 1.93 & 1.34 & 1.35 & 1.07 \\
\hline $\mathrm{Cr}_{2} \mathrm{O}_{3}$ & 1.26 & 1.24 & 2.24 & 17.47 & 17.08 & 17.29 & 16.62 & 17.46 & 20.49 & 21.00 & 11.84 \\
\hline $\mathrm{V}_{2} \mathrm{O}_{3}{ }^{\mathrm{a}}$ & 0.85 & 0.82 & 1.29 & 0.92 & 0.89 & 0.89 & 0.97 & 0.94 & 0.71 & 0.69 & 0.55 \\
\hline $\mathrm{Nb}_{2} \mathrm{O}_{5}$ & $<0.01$ & $<0.01$ & $<0.01$ & 0.13 & 0.17 & 0.10 & 0.13 & 0.16 & 0.01 & 0.02 & 0.01 \\
\hline $\mathrm{FeO}^{\mathrm{b}}$ & 11.61 & 11.64 & 9.90 & 10.44 & 10.40 & 10.26 & 10.81 & 10.88 & 8.06 & 8.10 & 8.99 \\
\hline $\mathrm{MgO}$ & 4.21 & 4.05 & 3.96 & 3.17 & 3.16 & 3.13 & 3.22 & 3.20 & 2.84 & 2.83 & 3.76 \\
\hline $\mathrm{MnO}$ & 0.11 & 0.10 & 0.04 & 0.07 & 0.05 & 0.06 & 0.09 & 0.12 & 0.12 & 0.10 & 0.13 \\
\hline $\mathrm{NiO}$ & 0.51 & 0.48 & 0.43 & 0.04 & 0.08 & 0.04 & 0.14 & 0.05 & 0.11 & 0.09 & 0.22 \\
\hline $\mathrm{La}_{2} \mathrm{O}_{3}$ & 0.01 & $<0.01$ & $<0.01$ & 2.63 & 2.75 & 2.80 & 2.68 & 2.71 & 0.33 & 1.05 & 0.02 \\
\hline $\mathrm{Ce}_{2} \mathrm{O}_{3}$ & 0.38 & 0.54 & 0.36 & 2.00 & 2.02 & 1.99 & 1.86 & 2.14 & 1.31 & 2.04 & 0.50 \\
\hline $\mathrm{CaO}$ & 2.33 & 2.41 & 1.96 & 0.48 & 0.46 & 0.49 & 0.49 & 0.58 & 1.42 & 0.66 & 1.06 \\
\hline $\mathrm{SrO}$ & 0.71 & 0.68 & 0.62 & 3.86 & 3.87 & 3.60 & 3.56 & 3.48 & 2.59 & 3.33 & 3.15 \\
\hline $\mathrm{BaO}$ & 1.49 & 1.49 & 1.34 & 1.17 & 1.09 & 1.24 & 1.05 & 1.09 & 0.20 & 1.64 & 0.22 \\
\hline $\mathrm{Na}_{2} \mathrm{O}$ & 0.48 & 0.41 & 0.54 & 0.04 & 0.04 & 0.04 & 0.05 & 0.04 & 0.21 & 0.07 & 0.45 \\
\hline $\mathrm{K}_{2} \mathrm{O}$ & 0.31 & 0.32 & 0.33 & 0.03 & $<0.01$ & 0.03 & 0.02 & 0.01 & 0.36 & 0.03 & 0.36 \\
\hline Total & 99.21 & 99.11 & 99.37 & 99.96 & 99.26 & 99.71 & 99.88 & 100.42 & 100.26 & 100.35 & 99.99 \\
\hline
\end{tabular}

\footnotetext{
${ }^{a}$ After corrections for Ti interference; total $\mathrm{V}$ as $\mathrm{V}_{2} \mathrm{O}_{3}$
}

${ }^{\mathrm{b}}$ Total $\mathrm{Fe}$ as $\mathrm{FeO}$ 
The rutile inclusions also contain a significant amount of a hydrous component in the form of $\mathrm{OH}$. The calculated concentrations of $\mathrm{OH}$ from microprobe analyses range from $\sim 0.2$ to $\sim 0.9 \mathrm{wt} \% \mathrm{H}_{2} \mathrm{O}$ (Table 7). The $\mathrm{OH}$ content of rutile in sample GRPy-39 has been confirmed by IR measurement. The IR data gave $\sim 0.8 \mathrm{wt} \% \mathrm{H}_{2} \mathrm{O}$ using the calibration of Hammer and Beran (1991), consistent with the calculated value $\left(0.88 \mathrm{wt} \% \mathrm{H}_{2} \mathrm{O}\right)$. Previous studies have shown a good correlation between calculated and measured $\mathrm{OH}$ concentrations in rutile (e.g., Hammer and Beran 1991; Vlassopoulos et al. 1993). The $\mathrm{OH}$ content of the rutiles is positively related to that of their pyrope hosts (Fig. 5b), implying some kind of equilibrium partitioning, although the equilibrium reaction is not clear.

\section{Spinel}

Monomineralic spinel inclusions (texture I) are rare, with one grain being identified in sample GRPy-21 (Fig. 6a) and one in sample GRPy-8. These two spinel inclusions are believed to have the same peridotitic origin as olivine, enstatite and diopside inclusions (texture I). Their $\mathrm{Cr} \# \mathrm{~s}$ are $\sim 30$ to $\sim 40$ (Table 8). Needle or tabular spinel coexists only with chromian rutile (sample GRPy-39; texture II; Fig. 6b). They appear to be intergrown, and spinel has much higher $\mathrm{Cr} \#$ and $\mathrm{Ti}$ concentration (Table 8). The third type of spinel occurs as euhedral-to-subhedral grains in composite inclusions (texture III; Fig. 1g; Smith 1987). The $\mathrm{Cr} \#$ of these spinel grains ranges from less than 10 (sample GRPy-6) to 30 (sample GRPy-16, Table 8). The fourth and commonest spinel occurs as small irregular-shaped grains at the boundary between large olivine inclusions and the pyrope host, and is commonly associated with rutile, ilmenite and carbonate (texture IV; Fig. 1h). These spinel grains are aluminous with low and variable $\mathrm{Cr} \#(<20)$ (sample GRPy-15, Table 8). The presence of rutile and carbonate together with spinel and the absence of enstatite in this association make it unlikely that they are products of retrograde subsolidus reaction between olivine and garnet host. Finally, irregular chromites were found as inclusions in two garnet crystals (GRPy-7 and GRPy37; texture V; Fig. 6c). They coexist with chromian diopside and amphibole. Chlorite and barite were identified adjacent to this assemblage in sample GRPy37. The BSE images and chemical analyses show that in both garnets there is complex compositional zonation surrounding chromite and associated inclusions (Fig. 6d).
Fig. 4a-d BSE images of srilankite inclusions and their coexisting minerals: a Slk + Ilm + Rt (GRPy-29); b Slk + Rt + Ilm (GRPy-34); c Slk + Cml + Rt (GRPy-39); d Slk $+\mathrm{Rt}+\mathrm{Ol}($ GRPy-36)
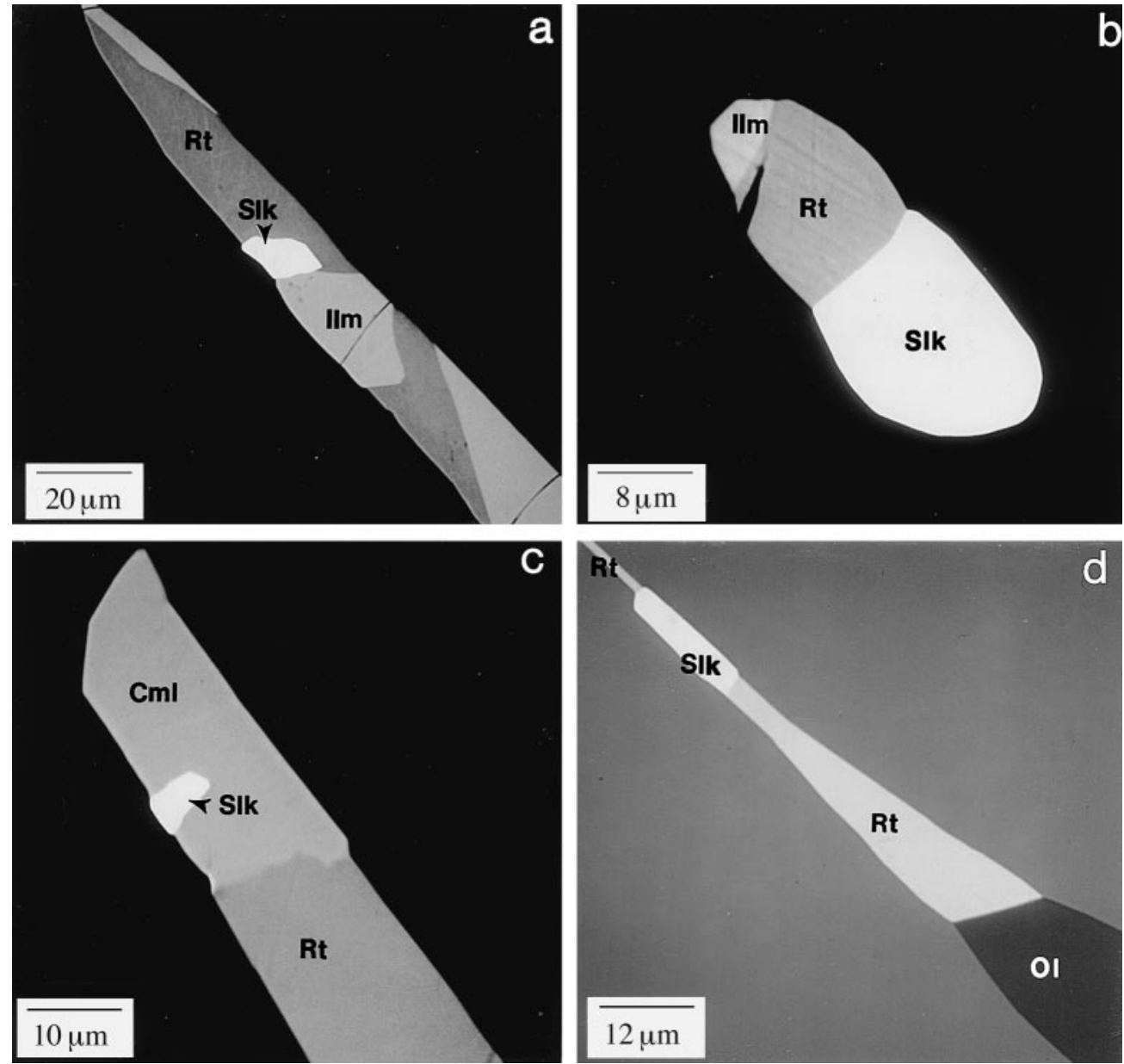
Table 6 Analyses of srilankite

\begin{tabular}{|c|c|c|c|c|c|c|c|c|c|c|}
\hline $\begin{array}{l}\text { Sample no. } \\
\text { Grain no. }\end{array}$ & \multicolumn{2}{|c|}{ GRPy-29 } & \multicolumn{6}{|c|}{ GRPy-34 } & $\begin{array}{l}\text { GRPy-36 } \\
1\end{array}$ & $\begin{array}{l}\text { GRPy-39 } \\
1\end{array}$ \\
\hline $\mathrm{ZrO}_{2}$ & 43.28 & 43.95 & 43.41 & 43.28 & 43.60 & 43.33 & 44.36 & 43.49 & 43.42 & 42.56 \\
\hline $\mathrm{HfO}_{2}$ & 0.52 & 0.43 & 0.58 & 0.57 & 0.29 & 0.41 & 0.34 & 0.33 & 0.62 & 0.44 \\
\hline $\mathrm{SiO}_{2}$ & 0.08 & $<0.01$ & 0.04 & 0.11 & 0.03 & $<0.01$ & 0.04 & $<0.01$ & 0.05 & $<0.01$ \\
\hline $\mathrm{Al}_{2} \mathrm{O}_{3}$ & 0.16 & 0.06 & 0.10 & 0.10 & 0.06 & 0.06 & 0.10 & 0.07 & 0.06 & 0.07 \\
\hline $\mathrm{FeO}^{\mathrm{b}}$ & 0.53 & 0.40 & 0.53 & 0.61 & 0.49 & 0.31 & 0.52 & 0.46 & 0.48 & 0.57 \\
\hline $\mathrm{MgO}$ & 0.07 & 0.01 & 0.04 & 0.07 & 0.02 & $<0.01$ & 0.04 & 0.03 & 0.03 & 0.03 \\
\hline $\mathrm{MnO}$ & 0.01 & 0.02 & 0.02 & 0.02 & 0.03 & 0.01 & $<0.01$ & 0.03 & 0.01 & $<0.01$ \\
\hline $\mathrm{CaO}$ & 0.12 & 0.04 & 0.17 & 0.24 & 0.08 & 0.07 & 0.17 & 0.07 & 0.14 & 0.11 \\
\hline Total & 99.67 & 100.39 & 100.34 & 99.96 & 100.49 & 99.74 & 100.36 & 100.01 & 100.76 & 100.76 \\
\hline
\end{tabular}

${ }^{a}$ After corrections for $\mathrm{Ti}$ interference; all $\mathrm{V}$ as $\mathrm{V}_{2} \mathrm{O}_{3}$

${ }^{\mathrm{b}} \mathrm{All} \mathrm{Fe}$ as $\mathrm{FeO}$

\section{Ilmenite}

Ilmenite is present as single inclusions, and it may coexist with rutile, srilankite, loveringite, spinel, and silicates (such as enstatite) (Figs. 3a, 4a, b). Ilmenite is commonly intergrown with rutile. The ilmenite grains are calculated to have 50-60 mol\% geikielite and 2-4 mol\% hematite (Table 9). They also contain $0.1-1.4 \mathrm{~mol} \%$ eskolaite, which is related to the $\mathrm{Cr}$ concentration of the pyrope host (Fig. 5a). Compared to those from South Africa kimberlite (e.g., Haggerty 1983; Schulze 1990), Garnet Ridge ilmenite has a lower Cr content.
Carmichaelite

Carmichaelite is a new mineral (approved by CNMMNIMA) that was discovered as inclusions in these pyrope crystals, with a formula of $\mathrm{MO}_{2-\mathrm{x}}(\mathrm{OH})_{\mathrm{x}}$, where $\mathrm{M}$ mainly includes $\mathrm{Ti}, \mathrm{Cr}, \mathrm{Al}$ and $\mathrm{Mg}$ (Wang et al. 1998). Carmichaelite inclusions coexist with rutile and/or srilankite. One grain from sample GRPy-40 has the following composition (in wt \%): $\mathrm{TiO}_{2}, 61.91 ; \mathrm{Cr}_{2} \mathrm{O}_{3}, 17.98$; $\mathrm{Al}_{2} \mathrm{O}_{3}, 2.06 ; \mathrm{V}_{2} \mathrm{O}_{3}, 1.00 ; \mathrm{Nb}_{2} \mathrm{O}_{5}, 0.78 ; \mathrm{FeO}, 7.85 ; \mathrm{MgO}$, 2.74. This composition is similar to that of crichtonite, but carmichaelite contains a higher total of $\mathrm{Ti}+\mathrm{Cr}$, a

Table 7 Representative analyses of rutile

\begin{tabular}{|c|c|c|c|c|c|c|c|c|c|}
\hline $\begin{array}{l}\text { Sample no. } \\
\text { Grain no. }\end{array}$ & $\begin{array}{l}\text { GRPy-1 } \\
1\end{array}$ & $\begin{array}{l}\text { GRPy-4 } \\
1\end{array}$ & $\begin{array}{l}\text { GRPy-18 } \\
1\end{array}$ & $\begin{array}{l}\text { GRPy-25 } \\
1\end{array}$ & $\begin{array}{l}\text { GRPy-29 } \\
1\end{array}$ & $\underset{1}{\text { GRPy-34 }}$ & $\begin{array}{l}\text { GRPy-36 } \\
1\end{array}$ & $\underset{1}{\text { GRPy-39 }}$ & $\begin{array}{l}\text { GRPy-40 } \\
1\end{array}$ \\
\hline $\mathrm{TiO}_{2}$ & 91.22 & 93.49 & 92.32 & 94.79 & 94.81 & 97.36 & 92.52 & 90.95 & 87.55 \\
\hline $\mathrm{ZrO}_{2}$ & 0.15 & 0.22 & 0.23 & 0.30 & 0.10 & 0.33 & 0.07 & 0.28 & 0.04 \\
\hline $\mathrm{SiO}_{2}$ & 0.14 & 0.03 & 0.17 & 0.03 & 0.01 & 0.04 & 0.04 & 0.03 & 0.04 \\
\hline $\mathrm{Cr}_{2} \mathrm{O}_{3}$ & 5.24 & 3.45 & 2.37 & 1.70 & 0.78 & 0.40 & 4.54 & 5.55 & 6.05 \\
\hline $\mathrm{Al}_{2} \mathrm{O}_{3}$ & 0.11 & 0.15 & 0.15 & 0.19 & 0.23 & 0.21 & 0.12 & 0.13 & 0.17 \\
\hline $\mathrm{V}_{2} \mathrm{O}_{3}{ }^{\mathrm{a}}$ & 0.52 & 0.58 & 0.55 & 0.50 & 0.99 & 0.60 & 0.56 & 0.61 & 0.66 \\
\hline $\mathrm{Fe}_{2} \mathrm{O}_{3}{ }^{\mathrm{b}}$ & 1.49 & 1.70 & 0.90 & 1.59 & 1.66 & 0.58 & 0.95 & 1.08 & 1.49 \\
\hline $\mathrm{Nb}_{2} \mathrm{O}_{5}$ & 0.03 & 0.05 & 2.73 & 0.20 & 0.07 & 0.10 & 0.12 & 0.06 & 2.56 \\
\hline $\mathrm{MgO}$ & 0.09 & 0.03 & 0.05 & 0.03 & 0.05 & $<0.01$ & 0.04 & 0.02 & 0.03 \\
\hline $\mathrm{H}_{2} \mathrm{O}^{\mathrm{c}}$ & 0.91 & 0.71 & 0.31 & 0.47 & 0.46 & 0.22 & 0.74 & 0.88 & 0.83 \\
\hline Total & 99.90 & 100.41 & 99.78 & 99.80 & 99.16 & 99.84 & 99.70 & 99.59 & 99.42 \\
\hline \multicolumn{10}{|c|}{ Formulae normalized to 1 cation } \\
\hline $\mathrm{Ti}$ & 0.917 & 0.935 & 0.936 & 0.953 & 0.958 & 0.977 & 0.932 & 0.919 & 0.893 \\
\hline $\mathrm{Zr}$ & 0.001 & 0.001 & 0.002 & 0.002 & 0.001 & 0.002 & 0.000 & 0.002 & 0.000 \\
\hline $\mathrm{Si}$ & 0.002 & 0.000 & 0.002 & 0.000 & 0.000 & 0.001 & 0.001 & 0.000 & 0.001 \\
\hline $\mathrm{Cr}$ & 0.055 & 0.036 & 0.025 & 0.018 & 0.008 & 0.004 & 0.048 & 0.059 & 0.065 \\
\hline $\mathrm{Al}$ & 0.002 & 0.002 & 0.002 & 0.003 & 0.004 & 0.003 & 0.002 & 0.002 & 0.003 \\
\hline $\mathrm{V}^{3+}$ & 0.006 & 0.006 & 0.006 & 0.005 & 0.011 & 0.006 & 0.006 & 0.007 & 0.007 \\
\hline $\mathrm{Fe}^{3+}$ & 0.015 & 0.017 & 0.009 & 0.016 & 0.017 & 0.006 & 0.010 & 0.011 & 0.015 \\
\hline $\mathrm{Nb}^{5+}$ & 0.000 & 0.000 & 0.017 & 0.001 & 0.000 & 0.001 & 0.001 & 0.000 & 0.016 \\
\hline $\mathrm{Mg}$ & 0.002 & 0.001 & 0.001 & 0.001 & 0.001 & 0.000 & 0.001 & 0.000 & 0.001 \\
\hline $\mathrm{H}^{\mathrm{c}}$ & 0.081 & 0.063 & 0.028 & 0.042 & 0.041 & 0.019 & 0.066 & 0.079 & 0.075 \\
\hline
\end{tabular}

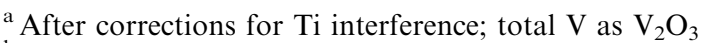

${ }^{\mathrm{c}} \mathrm{H}$ calculated assuming charge balance $(H=\mathrm{Cr}+\mathrm{Al}+\mathrm{V}+$

${ }^{\mathrm{b}}$ Total $\mathrm{Fe}$ as $\mathrm{Fe}_{2} \mathrm{O}_{3}$

$\left.\mathrm{Fe}^{3+}+2 * \mathrm{Mg}-\mathrm{Nb}\right)$ 
higher $\mathrm{Nb}$, and no appreciable LILE and Zr. Microprobe and IR analyses indicate that it contains a high concentration of $\mathrm{OH}\left(5-6 \mathrm{wt} \% \mathrm{H}_{2} \mathrm{O}\right)$.

\section{Discussion}

\section{Thermobarometry}

There have been previous attempts to construct pressure-temperature history for the pyrope crystals and associated inclusions brought up by the diatremes on the Colorado Plateau (McGetchin and Silver 1970; Smith and Levy 1976; Hunter and Smith 1981; Smith 1987; Griffin and Ryan 1995). The compositions of pyrope host and various inclusions were used in previous studies. However, due to differential compressibilities and thermal expansivities, the pressure in an inclusion may not be the same as the host pressure (lithostatic pres-
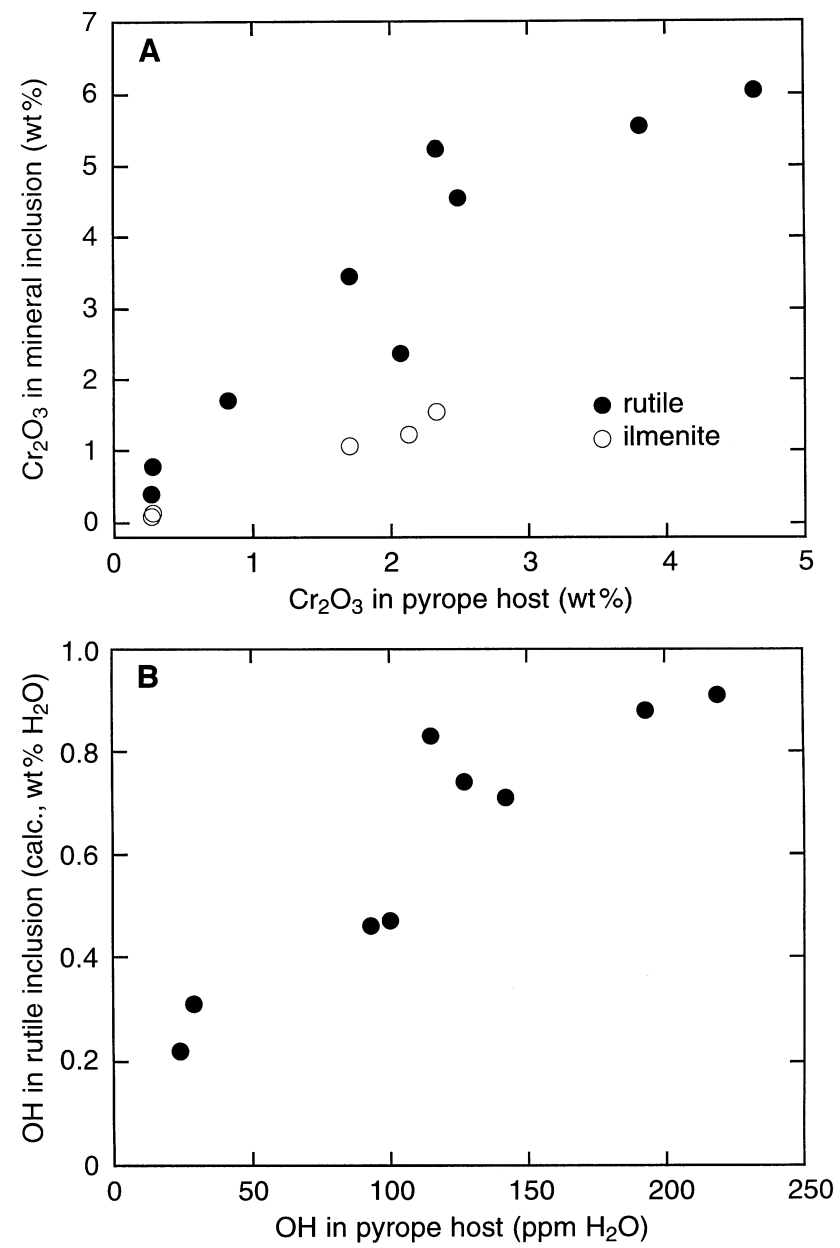

Fig. 5 a Relationship between $\mathrm{Cr}$ content of oxide inclusions (rutile and ilmenite) and that of pyrope hosts. The errors for $\mathrm{Cr}_{2} \mathrm{O}_{3}$ analysis in both inclusion and host are about the size of symbol. b Relationship between calculated $\mathrm{OH}$ concentration in rutile and measured $\mathrm{OH}$ content in pyrope host. The relative error in IR analysis is typically $2-$ $3 \%$, and the accuracy in the $\mathrm{OH}$ content (in $\mathrm{ppm}_{2} \mathrm{O}$ ) depends on the accuracy of calibration (Bell et al. 1995) sure). The pressure in different inclusions in a single host may also be different if the temperature on the assemblages or the pressure on the host varied owing to motion in the mantle (e.g., Gillet et al. 1984; Zhang 1998). Thus estimation of $P$ and $T$ could be complicated if the physical conditions have changed after the formation of host-inclusion assemblage.

A straightforward method to estimate the formation pressure for the pyrope crystals is the use of $\mathrm{Cr}$ content in garnet coexisting with olivine. As more than $60 \%$ of pyrope crystals examined contain olivine inclusions, it is almost certain that pyrope formed in the presence of olivine. Compositional exchange with inclusions is not expected to affect the bulk composition of the pyrope host because the volume of the host is much larger than that of the inclusions. Assuming pyrope composition has not changed after formation, the minimum formation pressure can be estimated using the equilibrium: $\mathrm{Opx}+\mathrm{Sp}=\mathrm{Ol}+\mathrm{Gt}$ (Webb and Wood 1986). The formation pressure of pyrope equilibrated with olivine is a strong function of its $\mathrm{Cr}$ content and only weakly depends on temperature and $\mathrm{Mg}$ \#. Assuming a formation temperature of $600-900{ }^{\circ} \mathrm{C}$, the minimum formation pressure ranges from $\sim 15 \mathrm{kbar}$ for pyrope with $\mathrm{Cr} \#$ of 0.8 to $\sim 30 \mathrm{kbar}$ for pyrope with Cr\# of 16 .

Because phase equilibria between host-inclusion pairs may be complicated (Zhang 1998), the complexity may be avoided by considering only the formation $T$ and $P$ conditions using inclusion and host compositions at formation. The presence of two pyroxenes as separate inclusions in single pyrope host (Table 3 ) provides a rare opportunity to apply two-pyroxene thermobarometry to constrain the $P-T$ of formation. It is assumed that the core composition of the two pyroxenes has not been altered after incorporation in pyrope. Unlike olivine, whose compositions vary with the grain size in a single pyrope (Hunter and Smith 1981; Smith and Wilson 1985; this study, Fig. 2a and Table 3), large pyroxenes may preserve their original compositions at their cores. This is demonstrated by the compositional similarities in the mineral cores among pyroxene inclusions with different size. Use of the two-pyroxene thermometer and Al-in-opx barometer formulated by Brey and Kohler (1990) yields $580{ }^{\circ} \mathrm{C}$ and $16 \mathrm{kbar}$ for sample GRPy-8, and $620^{\circ} \mathrm{C}$ and $18 \mathrm{kbar}$ for sample GRPy-15. These pressures are somewhat lower than minimum pressures estimated from the $\mathrm{Cr}$ contents of pyrope ( $\sim 20 \mathrm{kbar}$ for GRPy- 8 and $\sim 22 \mathrm{kbar}$ for GRPy15). The temperatures are about $200-300{ }^{\circ} \mathrm{C}$ lower than those obtained in previous studies using earlier versions of pyroxene-garnet thermometer and Al-in-opx barometer (McGetchin and Silver 1970; Hunter and Smith 1981).

The formation temperature can also be estimated from the $\mathrm{Fe}$ and $\mathrm{Mg}$ contents of olivine inclusion and pyrope host (O'Neill and Wood 1979). The composition of olivine at time of formation is obtained by integrating the Fe-Mg profile in the pyrope host (i.e., Fig. 2b), assuming the garnet composition was initially uniform. 
Fig. 6a-d BSE images of spinel inclusions and their coexisting minerals: a Spl (GRPy-21); b Spl + Rt (GRPy-39); (c)

$\mathrm{Spl}+\mathrm{Di}+$ Amp (GRPy-37); d same inclusion assemblage as in $\mathbf{c}$ with lower magnification. Notice the contrast in pyrope host. Darker area has lower Cr and $\mathrm{Ca}$ contents
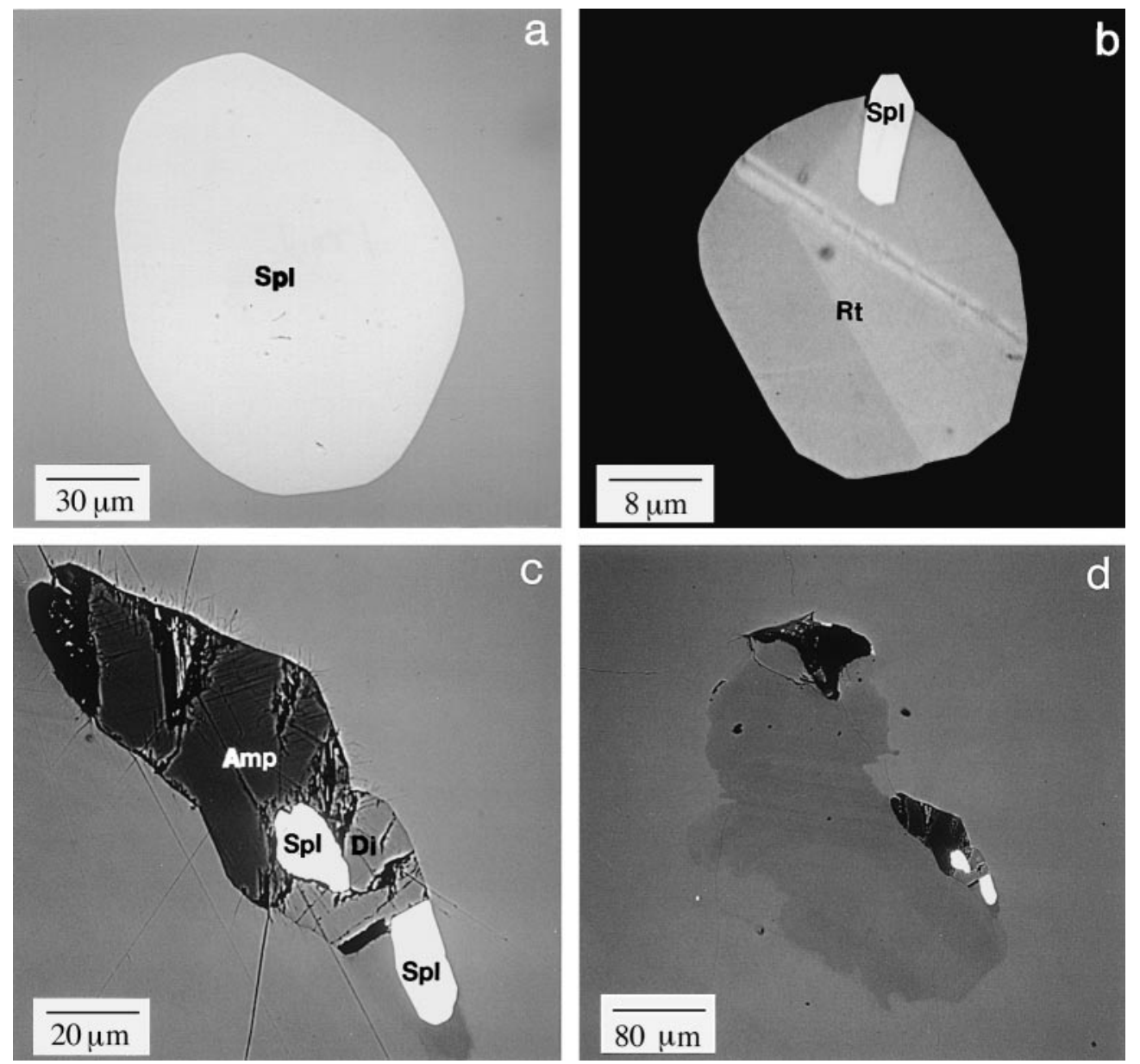

For two olivine inclusions in sample GRPy-15, the reconstructed original $\mathrm{Mg \#}$ is 93.5 for a large olivine inclusion $(\mathrm{Ol}-2 ; \mathrm{Mg \#}=94.0)$, with a nearly identical value (93.6) for a small inclusion $(\mathrm{Ol}-1 ; \mathrm{Mg \#}=95.1)$, confirming the validity of this approach. Using the original olivine $\mathrm{Mg \# s}$ and pyrope composition distant from the olivine, the olivine-garnet thermometer of
O'Neill and Wood (1979) yields $620{ }^{\circ} \mathrm{C}$, consistent with the result using the two-pyroxene thermometer. If the present $\mathrm{Mg \# s}$ of the olivine inclusions are used, the calculated temperatures would be 40 to $140{ }^{\circ} \mathrm{C}$ lower than $620^{\circ} \mathrm{C}$, depending on the inclusion size. Using the same approach, the formation temperature for a pyrope crystal (GRPy-37) with the highest $\mathrm{Cr}_{2} \mathrm{O}_{3}$ content of
Table 8 Representative analyses of spinel

\begin{tabular}{lcclllrr}
\hline $\begin{array}{l}\text { Sample no. } \\
\text { Grain no. }\end{array}$ & $\begin{array}{l}\text { GRPy-6 } \\
1(\mathrm{III})^{\mathrm{a}}\end{array}$ & $\begin{array}{l}\text { GRPy-7 } \\
1(\mathrm{~V})\end{array}$ & $\begin{array}{l}\text { GRPy-8 } \\
1(\mathrm{I})\end{array}$ & $\begin{array}{l}\text { GRPy-15 } \\
1(\mathrm{IV})\end{array}$ & $\begin{array}{l}\text { GRPy-16 } \\
1(\mathrm{III})\end{array}$ & $\begin{array}{l}\text { GRPy-21 } \\
1(\mathrm{I})\end{array}$ & $\begin{array}{l}\text { GRPy-39 } \\
1 \text { (II) }\end{array}$ \\
\hline $\mathrm{MgO}$ & 22.37 & 10.19 & 14.86 & 19.01 & 18.67 & 18.27 & 10.25 \\
$\mathrm{FeO}^{\mathrm{b}}$ & 6.76 & 19.54 & 14.60 & 10.91 & 9.26 & 10.88 & 19.67 \\
$\mathrm{CaO}$ & 0.17 & 0.08 & 0.11 & $\mathrm{ND}^{\mathrm{c}}$ & 0.11 & 0.02 & 0.06 \\
$\mathrm{NiO}$ & 0.41 & $<0.01$ & 0.15 & 0.28 & 0.38 & 0.39 & 0.17 \\
$\mathrm{MnO}$ & $\mathrm{ND}$ & $\mathrm{ND}$ & 0.18 & $\mathrm{ND}$ & 0.12 & 0.13 & 0.25 \\
$\mathrm{Al}_{2} \mathrm{O}_{3}$ & 63.20 & 8.85 & 35.19 & 51.67 & 44.79 & 43.42 & 11.53 \\
$\mathrm{Cr}_{2} \mathrm{O}_{3}$ & 6.81 & 61.46 & 34.47 & 17.90 & 26.30 & 27.02 & 56.01 \\
$\mathrm{TiO}_{2}$ & $\mathrm{ND}$ & $\mathrm{ND}$ & 0.24 & 0.01 & 0.06 & 0.04 & 1.43 \\
$\mathrm{Total}$ & 99.72 & 100.12 & 99.78 & 99.77 & 99.69 & 100.17 & 99.37 \\
$\mathrm{Mg}^{\text {d }}$ & 14.5 & 49.6 & 35.5 & 24.1 & 21.8 & 24.4 & 50.8 \\
$\mathrm{Cr}^{\mathrm{e}}$ & 6.7 & 82.3 & 39.7 & 18.9 & 28.3 & 29.5 & 76.5 \\
\hline
\end{tabular}

${ }^{\text {a }}$ Numbers in parentheses indicating spinel texture ( $I$ monomineralic, $I I$ with rutile, $I I I$ in composite inclusion, $I V$ interboundary grain, $V$ with amphibole and diopside)

${ }^{\mathrm{b}}$ Total $\mathrm{Fe}$ as $\mathrm{FeO}$

${ }^{\mathrm{c}}$ (ND not determined)

${ }^{\mathrm{d}} \mathrm{Mg} \#=100 * \mathrm{Mg} /(\mathrm{Mg}+\mathrm{Fe})$

${ }^{\mathrm{e}} \mathrm{Cr} \#=100 * \mathrm{Cr} /(\mathrm{Al}+\mathrm{Cr})$ 
Table 9 Representative analyses of ilmenite

\begin{tabular}{|c|c|c|c|c|c|}
\hline $\begin{array}{l}\text { Sample no. } \\
\text { Grain no. }\end{array}$ & $\begin{array}{c}\text { GRPy-1 } \\
1\end{array}$ & $\begin{array}{l}\text { GRPy-4 } \\
2\end{array}$ & $\begin{array}{l}\text { GRPy-15 } \\
1\end{array}$ & $\begin{array}{l}\text { GRPy-29 } \\
1\end{array}$ & $\begin{array}{l}\text { GRPy-34 } \\
2\end{array}$ \\
\hline $\mathrm{TiO}_{2}$ & 54.89 & 55.71 & 56.86 & 57.31 & 58.37 \\
\hline $\mathrm{SiO}_{2}$ & 0.11 & 0.08 & 0.06 & $<0.01$ & 0.02 \\
\hline $\mathrm{Al}_{2} \mathrm{O}_{3}$ & 0.09 & 0.05 & 0.08 & 0.04 & 0.08 \\
\hline $\mathrm{Cr}_{2} \mathrm{O}_{3}$ & 1.54 & 1.06 & 1.22 & 0.14 & 0.09 \\
\hline $\mathrm{V}_{2} \mathrm{O}_{3}{ }^{\mathrm{a}}$ & 0.07 & 0.09 & 0.14 & 0.05 & $<0.01$ \\
\hline $\mathrm{Nb}_{2} \mathrm{O}_{5}$ & 0.05 & $<0.01$ & 0.03 & 0.01 & $<0.01$ \\
\hline $\mathrm{FeO}^{\mathrm{b}}$ & 27.99 & 28.00 & 24.89 & 26.42 & 22.20 \\
\hline $\mathrm{MgO}$ & 14.04 & 13.63 & 15.73 & 14.81 & 17.71 \\
\hline $\mathrm{CaO}$ & 0.18 & 0.17 & 0.07 & 0.08 & 0.05 \\
\hline $\mathrm{MnO}$ & 0.19 & 0.20 & 0.14 & 0.22 & 0.07 \\
\hline $\mathrm{NiO}$ & 0.61 & 0.49 & 1.01 & 0.46 & 1.46 \\
\hline Total & 99.76 & 99.48 & 100.2 & 99.54 & 100.1 \\
\hline Geikielite & 0.484 & 0.472 & 0.537 & 0.507 & 0.602 \\
\hline Ilmenite & 0.455 & 0.485 & 0.422 & 0.469 & 0.370 \\
\hline Hematite & 0.043 & 0.029 & 0.027 & 0.019 & 0.026 \\
\hline Eskolaite & 0.014 & 0.010 & 0.027 & 0.001 & 0.001 \\
\hline
\end{tabular}

${ }^{a}$ After corrections for $\mathrm{Ti}$ interference; total $\mathrm{V}$ as $\mathrm{V}_{2} \mathrm{O}_{3}$

${ }^{b}$ Total $\mathrm{Fe}$ as $\mathrm{FeO}$

$\sim 5.7 \%$ and containing an olivine inclusion with original $\mathrm{Mg} \# 92.2$ is $810{ }^{\circ} \mathrm{C}$ at $30 \mathrm{kbar}$.

In summary, the calculated formation temperature and pressure covary as expected: (1) $580{ }^{\circ} \mathrm{C}$ at $16 \mathrm{kbar}$ for GRPy-8 based on the two-pyroxene thermometer and Al-in-opx (coexisting with garnet) barometer; (2) $620{ }^{\circ} \mathrm{C}$ at $18 \mathrm{kbar}$ for GRPy-15 based on the two-pyroxene thermometer, Al-in-opx (coexisting with garnet) barometer, and $\mathrm{Fe}-\mathrm{Mg}$ exchange thermometer between olivine and pyrope; (3) $810{ }^{\circ} \mathrm{C}$ at $30 \mathrm{kbar}$ for GRPy-37 based on $\mathrm{Cr}_{2} \mathrm{O}_{3}$ in pyrope and $\mathrm{Fe}-\mathrm{Mg}$ exchange thermometer between olivine and pyrope. Furthermore, the $\mathrm{Cr}_{2} \mathrm{O}_{3}$ contents of pyrope hosts give the minimum formation pressures, which are close to the actual formation pressures as shown in cases where pressures can be obtained from the Al-in-opx barometer. Therefore, we estimate that pyrope crystals with different $\mathrm{Cr}$ content formed at different depths ranging from $50 \mathrm{~km}$ (where $T \approx 600^{\circ} \mathrm{C}$ and $P=15 \mathrm{kbar}$ ) to $95 \mathrm{~km}$ (where $T \approx 800{ }^{\circ} \mathrm{C}$ and $P=30 \mathrm{kbar}$ ) along the local ancient geotherm (corresponding to a heat flow of $40-50 \mathrm{~mW} /$ $\mathrm{m}^{2}$; Chapman and Pollack 1977). These garnets then subsequently experienced cooling in the mantle, as recorded by: (1) the $\mathrm{Fe}-\mathrm{Mg}$ composition profile in pyrope next to olivine inclusions; (2) the relation between olivine size and $\mathrm{Mg \#} \mathrm{(Fig.} \mathrm{2).} \mathrm{The} \mathrm{cooling} \mathrm{may}$ change the inclusion pressure and produce stress around inclusions because of the difference in thermal expansivity of pyrope host and inclusion minerals. The last equilibrium $T$ and $P$ cannot directly be estimated from host-inclusion assemblage (i.e., pyrope-olivine) since the effect of stress on phase equilibria is difficult to quantify (Zhang 1998). The reported $P-T$ values calculated from the compositions near the contacts for various pyropeinclusion pairs (Hunter and Smith 1981; Smith 1987; Smith and Barron 1991) should hence be treated with caution because the uncertainties in such calculations are difficult to assess. Nevertheless, a final temperature of $\sim 100{ }^{\circ} \mathrm{C}$ lower than the formation temperatures before diatreme eruption can be inferred from the mineral pairs in the same inclusions, such as coexisting olivinespinel and dolomite-magnesite (Smith 1987).

Exsolution origin for preferentially oriented needle rutile inclusions?

Needle rutile inclusions in pyrope crystals have long been suggested to be of exsolution origin, mainly based on their regularly spaced and preferentially oriented texture similar to that of typical exsolution (McGetchin and Silver 1970; Hunter and Smith 1981; Smith 1987). In the garnet crystals that we studied, there are two groups of needle inclusions, one consisting of needles with a diameter of $\sim 1 \mu \mathrm{m}$, and the other consisting of needles that are significantly larger $(\sim 10 \mu \mathrm{m})$. The larger needle inclusions have complicated mineralogy, commonly containing three or more different minerals in one needle. These larger needle inclusions are probably not of exsolution origin. For example, the chemistry of crichtonite series minerals (i.e., containing $\mathrm{Sr}$, $\mathrm{Ba}$ and LREE) in needle inclusions are difficult to explain by a simple exsolution origin for these inclusions, although they too have a preferentially oriented texture. These inclusions likely formed by epitaxial co-precipitation with their pyrope hosts. A similar origin for larger needle rutile inclusion is evidenced by the common coexistence and alignment of needle- or blade-like rutile with crichtonite series, srilankite, carmichaelite, carbonates and olivine (Figs. 1e, 3, 4). Such occurrences can not be explained by the preferred nucleation of rutile in the stressed pyrope surrounding other inclusions. The preferred nucleation of rutile has not been observed in the pyrope host near silicate inclusions (texture I), around which the pyrope was certainly stressed during cooling, as evidenced by fractures and birefringent halos in host.

Our inference that the lattice preferred orientation (LPO) of Ti-rich oxides in pyrope does not have to be exsolution origin may have applications to other cases in which an exsolution mechanism is often invoked, such as LPO of rutile in eclogitic garnet (Haggerty 1991b), LPO of rutile in pyrope, and ilmenite and chromite in olivine (Dobrzhinetskaya et al. 1996). The clarification of this issue may also have important implications for the understanding HFSE depletion in island arc basalts. Further experimental investigations and studies on natural samples are needed.

\section{Crichtonite series}

In crustal mafic and alkalic rocks, minerals of crichtonite series are commonly inferred to crystallize from late stage residual liquids or fluids (e.g., Campbell and Kelly 1978; Lorand et al. 1987), reflected by en- 
richment in incompatible elements. For crichtonite series minerals of the mantle association, there is a general consensus for an origin by mantle metasomatism (Erlank and Rickard 1977; Jones et al. 1982; Jones 1989; Haggerty 1983, 1991a). The metasomatic liquids have been inferred to be enriched in volatiles (i.e., $\mathrm{CO}_{2}$, $\mathrm{H}_{2} \mathrm{O}$ ), LILE (i.e., $\mathrm{K}, \mathrm{Ca}, \mathrm{Sr}, \mathrm{Ba}$ and REE) and HFSE ( $\mathrm{Ti}, \mathrm{Zr}$ and $\mathrm{Nb}$ ). The occurrence of crichtonite series reported in this study extends the spatial distribution of these minerals in the upper mantle and broadens the scope of considering them as an important storage site for LILE, HFSE and REE. It also demonstrates that not only "LIMA" (lindsleyite-mathiasite), but also other members of this series can be stable in the upper mantle. The presence of crichtonite-loveringite-davidite solid solutions instead of LIMA in our samples (Table 5) may reflect differences in the geochemical environment and physical conditions at which these minerals formed. The LIMA has been suggested to originate at $20-30 \mathrm{kbar}$ and $900-1100{ }^{\circ} \mathrm{C}$ (Haggerty 1983, 1991a), whereas crichtonite-loveringite-davidite series from our sample may crystallize at similar pressures, but at much lower temperatures.

\section{Srilankite}

Experimental investigations on the system $\mathrm{ZrO}_{2}-\mathrm{TiO}_{2}$ have been carried out by McHale and Roth (1986) and Willgallis et al. (1987). The phase $\mathrm{ZrTi}_{2} \mathrm{O}_{6}$ was found as the stable crystalline compound occurring at 1 atm pressure and $<1100{ }^{\circ} \mathrm{C}$, with a small range of $\mathrm{Zr} / \mathrm{Ti}$ solid solution (McHale and Roth 1986). Willgallis et al. (1987) synthesized srilankite at $128-635^{\circ} \mathrm{C}$ and $0.15-3.0 \mathrm{kbar}$ under hydrothermal conditions, and suggested that this mineral is to be regarded as of hydrothermal origin in nature. They inferred the presence of srilankite in run products from X-ray diffraction lines. Their experimental data seem to suggest a possible wide range of $\mathrm{Zr} / \mathrm{Ti}$ solid solution in srilankite, but it is difficult to assess the claim because they did not obtain compositional data for the run products by direct analysis and the identified phases may be metastable due to slow crystallization of ordered srilankite. Our data indicate a very small range in $\mathrm{Zr} / \mathrm{Ti}$ solid solution for srilankite coexisting with rutile (Table 6), consistent with the phase diagram of McHale and Roth (1986), but inconsistent with other phase diagrams for $\mathrm{ZrO}_{2}-\mathrm{TiO}_{2}$ at $1 \mathrm{~atm}$ (Levin and McMurdie 1975; Willgallis et al. 1987).

Presence of a fluid/melt phase and genesis of inclusions and their pyrope hosts

The presence of a fluid/melt phase during the formation of pyrope host crystals is directly shown by composite inclusions (texture III; Fig. 1g), which probably crystallized from trapped fluid/melt droplets (Smith 1987). The mineralogy of these inclusions demonstrates that the trapped fluid/melt is enriched in volatiles $\left(\mathrm{CO}_{2}, \mathrm{H}_{2} \mathrm{O}\right.$, $\mathrm{Cl}$ and $\mathrm{S}$ ) and incompatible elements (i.e., $\mathrm{Na}, \mathrm{K}, \mathrm{Ba}$ and P). The major composition of such inclusions, however, is dominated by the Al-rich amphibole and carbonates. An estimation of the major oxide concentrations for one composite inclusion (Fig. 1g) yields roughly (in wt\%): $\mathrm{SiO}_{2}, \sim 30 ; \mathrm{Al}_{2} \mathrm{O}_{3}, \sim 10 ; \mathrm{MgO}, \sim 20 ; \mathrm{FeO}, \sim 2 ; \mathrm{CaO}, \sim 15 ;$ $\mathrm{Na}_{2} \mathrm{O}+\mathrm{K}_{2} \mathrm{O}, \sim 4 ; \mathrm{CO}_{2}, \sim 15 ; \mathrm{H}_{2} \mathrm{O}, \sim 2$. This composition is best matched by a volatile- and $\mathrm{Mg}$-rich, silica-undersaturated melt. The relatively low $\mathrm{H}_{2} \mathrm{O}$ concentration, however, may not reflect the initial condition of the fluid/melt phase, because the diffusion of the hydrous component in pyrope is very rapid and $\mathrm{H}_{2} \mathrm{O}$ could be lost easily by diffusion through garnet (Wang et al. 1996). This fluid/melt phase differs from metasomatic melt that is trapped as secondary inclusions in minerals in some mantle xenoliths (e.g., Schiano and Clocchiatti 1994; Schiano et al. 1994, 1995), and may be related to mantle melting induced by $\mathrm{H}_{2} \mathrm{O}$ and $\mathrm{CO}_{2}$ fluid released from the subducting slab or other deep processes (e.g., Wyllie 1979, 1987).

The enrichment of highly incompatible elements in the exotic Ti-rich oxides and the high volatile concentration in some minerals also strongly support a role of fluid/melt phase and mantle metasomatism, as suggested for similar assemblages in veined peridotites and in kimberlite concentrates (e.g., Erlank and Rickard 1977; Jones et al. 1982; Haggerty 1983). As the oxide and composite inclusions probably formed at the same time, the oxide inclusions may directly be related to the fluid/ melt phase represented by composite inclusions. Alternatively, the oxides and composite inclusions may all be related to a parental fluid/melt phase (Smith 1987). The parental fluid/melt phase is thus originally enriched in volatiles (mainly $\mathrm{CO}_{2}, \mathrm{H}_{2} \mathrm{O}$ and $\mathrm{Cl}$ ) and incompatible elements (HFSE, LILE and REE) as typically suggested for mantle metasomatism.

The presence of a fluid/melt phase and the relationship between most inclusions and this phase constrain the genesis of host pyrope crystals. We conclude that most pyrope crystals, if not all, crystallized in the presence of the fluid/melt phase. Afterwards, garnet crystals experienced a prolonged cooling history, leading to $\mathrm{Fe}-\mathrm{Mg}$ interdiffusion profiles in garnet around olivine and other inclusions. The presence of some secondary inclusions (i.e., amphibole-diopside-chromite \pm chlorite \pm barite assemblage; Fig. 6c, d) indicates a later metasomatic event, which may but does not have to be related to the eruption of the ultramafic diatremes or minettes, commonly found in the same area (Roden 1981).

Metasomatism: decoupling of major and trace elements and HFSE depletion

There are two profound consequences of mantle metasomatism as observed in this study. One is related to the decoupling of major and trace elements, and the other is related to HFSE depletion. As a result of metasomatism, 
the depleted mantle region (with olivine $\mathrm{Mg \#} \mathrm{>} \mathrm{93)}$ where the pyrope crystals reside beneath the Colorado Plateau is enriched in incompatible minor and trace elements (i.e., high $\mathrm{Na}+\mathrm{K}$ in composite inclusions; the formation of crichtonite series and Ti-rich oxides). Therefore, the mantle region sampled by the garnet crystals provides an example of decoupling of major and trace elements, which has been invoked before to explain basalt chemistry (the classic model of Klein and Langmuir, 1987, can account for major element chemistry of MORB, but not their trace element chemistry). Such decoupling can be accomplished by first the depletion of mantle sources in both major and incompatible trace elements through extraction of melts, and then the enrichment of trace elements by mantle metasomatism.

The abundance of oxide inclusions in pyrope indicates that the oxide phases can crystallize from the fluid/ melt phase under certain conditions during mantle metasomatism, even though the exact conditions for their deposition is unknown. Many authors also reported the occurrence of Ti-rich oxide minerals or MORID (phlogopite-orthopyroxene-rutile-ilmenite diopside) veins in mantle xenoliths (e.g., Erlank and Rickard 1977; Jones et al. 1982; Zhao et al. 1998). The precipitation of Ti-rich minerals (rutile, crichtonites and ilmenite) leads to the depletion of the HFSE from the fluid/melt phase. If the residual fluid/melt is subsequently involved in magmatism and contributes a significant amount of other incompatible elements to magmas, there would be an HFSE depletion signal, a common feature for island arc basalts (IAB). Although the fluid/melt composition may be different in island arc settings, processes similar to those discussed in this work may lead to HFSE depletion in IAB. Hence, understanding the conditions for the formation of oxide phases from a fluid-rich melt, instead of partitioning between a fluid and a melt phase (Keppler 1996), or oxide precipitation from an almost anhydrous melt phase (Ryerson and Watson 1987), may be critical to the understanding HFSE depletion in IAB.

Acknowledgments We thank S. Dunn, S.C. Semken and A. Zaman for their help in field work, and the Navajo Nation for permission to collect samples. Critical reviews by D. Smith and an anonymous reviewer are greatly appreciated. Discussions with S.E. Haggerty, D.R. Peacor, R.C. Rouse, D. Smith, and P. Tropper helped improve the presentation. This study was supported by NSF grants EAR-9315918, 9458368 and 9725566, a research grant from NWT Geology Division of the Department of Indian Affairs and Northern Development, Canada, the Scott Turner Fund of the University of Michigan, and a research grant of the Geological Society of America. The electron microprobe at the University of Michigan was purchased with NSF grant EAR-8212764.

\section{References}

Aoki KI, Fujino K, Akaogi M (1976) Titanochondrodite and titanoclinohumite derived from the upper mantle in the Buell Park kimberlite, Arizona, USA. Contrib Mineral Petrol 56: 243-253
Bell DR (1993) Hydroxyl in mantle minerals. PhD thesis, California Inst Technol, Pasadena, CA

Bell DR, Ihinger PD, Rossman GR (1995) Quantitative analysis of trace $\mathrm{OH}$ in garnet and pyroxenes. Am Mineral 80: 465-474

Brey GP, Kohler T (1990) Geothermobarometry in four-phase lherzolites. II. New thermobarometers, and practical assessment of existing thermobarometers. J Petrol 31: 1353-1378

Campbell IH, Kelly PR (1978) The geochemistry of loveringite, a uranium-rare-earth-bearing accessory phase from Jimberlana intrusion of Western Australia. Mineral Mag 42: 187-193

Chapman D, Pollack HN (1977) Regional geotherms and lithospheric thickness. Geology 5: 265-268

Dobrzhinetskaya L, Green HW II, Wang S (1996) Alpe Arami: a peridotite massif from depths of more than 300 kilometers. Science 271: 1841-1848

Ehrenberg SN (1979) Garnetiferous ultramafic inclusions in minette from the Navajo volcanic field. In: Boyd FR, Meyer HOA (eds) The mantle sample: inclusions in kimberlites and other volcanics. Am Geophys Union, Washington, DC, pp 330 344

Erlank AJ, Rickard RS (1977) Potassic richterite bearing peridotites from kimberlite and the evidence they provide for upper mantle metasomatism. In: Extended Abstr, 2nd Int Kimberlite Conf, Santa Fe, New Mexico, USA, unpaged

Gatehouse BM, Grey IE, Campbell IH, Kelly P (1978) The crystal structure of loveringite - a new member of the crichtonite group. Am Mineral 63: 28-36

Gillet P, Ingrin J, Chopin C (1984) Coesite in subducted continental crust: $P-T$ history deduced from an elastic model. Earth Planet Sci Lett 70: 426-436

Grey IE, Lloyd DJ, White JJS (1976) The crystal structure of crichtonite and its relationship to senaite. Am Mineral 61: 1203-1212

Griffin WL, Ryan CG (1995) Trace elements in indicator minerals: area selection and target evaluation in diamond exploration. J Geochem Explor 53: 311-337

Haggerty SE (1975) The chemistry and genesis of opaque minerals in kimberlites. Phys Chem Earth 9: 295-307

Haggerty SE (1983) The mineral chemistry of new titanates from the Jagersfontein kimberlite, South Africa: implications for metasomatism in the upper mantle. Geochim Cosmochim Acta 47: $1833-1854$

Haggerty SE (1987) Metasomatic mineral titanates in upper mantle xenoliths. In: Nixon PH (ed) Mantle xenoliths. J Wiley and Sons, Chichester, pp 671-690

Haggerty SE (1991a) Oxide mineralogy of the upper mantle. In: Lindsley DH, Ribbe HP (eds) Oxide minerals: petrological and magnetic significance. (Reviews in Mineralogy, 25) Mineral Soc Am, Washington, DC, pp 355-416

Haggerty SE (1991b) Oxide textures - a mini-atlas. In: Lindsley DH, Ribbe HP (ed) Oxide minerals: petrological and magnetic significance. (Reviews in Mineralogy, 25) Mineral Soc Am, Washington, DC, pp 129-219

Haggerty SE, Smyth JR, Erlank AJ, Rickard RS, Danchin RV (1983) Lindsleyite (Ba) and mathiasite (K): two new chromium titanates in the crichtonite series from the upper mantle. Am Mineral 68: 494-505

Haggerty SE, Erlank AJ, Grey IE (1986) Metasomatic mineral titanate complexing in the upper mantle. Nature 319: 761-763

Hammer VMF, Beran A (1991) Variations in the OH concentration of rutiles from different geological environments. Mineral Petrol 45: 1-9

Helmstaedt H, Doig R (1975) Eclogite nodules from kimberlite pipes of the Colorado Plateau - samples of subducted Franciscan-type oceanic lithosphere. Phys Chem Earth 9: 95111

Helmstaedt H, Schulze DJ (1979) Garnet clinopyroxenite-chlorite eclogite transition in a xenolith from Moses Rock: further evidence for metamorphosed ophiolites under the Colorado Plateau. In: Boyd FR, Meyer HOA (eds) The mantle sample: inclusions in kimberlites and other volcanics. Am Geophys Union, Washington, pp 357-365 
Hunter WC, Smith D (1981) Garnet peridotite from Colorado Plateau ultramafic diatremes: hydrates, carbonates, and comparative geothermometry. Contrib Mineral Petrol 76: 312-320

Jones AP (1989) Upper-mantle enrichment by kimberlitic or carbonatitic magmatism. In: Bell K (ed) Carbonatites: genesis and evolution. Unwin Hyman Ltd, London, pp 448-463

Jones AP, Smith JV, Dawson JB (1982) Mantle metasomatism in 14 veined peridotites from Bultfontein mine, South Africa. J Geol 90: 435-453

Keppler H (1996) Constraints from partitioning experiments on the composition of subduction-zone fluids. Nature 380: 237-240

Klein EM, Langmuir CH (1987) Global correlations of ocean ridge basalt chemistry with axial depth and crustal thickness. J Geophys Res B92: 8089-8115

Kostrovitskiy SI, Garanin VK, Varlamov DA (1993) A second occurrence of srilankite. Trans Russ Acad Sci Earth Sci 329A: 133-137

Levin EM, McMurdie HF (1975) Phase diagrams for ceramists, 1975 supplement. In: Reser MK (ed) Am Ceram Soc, Columbus, p169

Lorand J-P, Cottin J-Y, Parodi GC (1987) Occurrence and petrological significance of loveringite in the western Laouni layered complex, southern Hoggar, Algeria. Can Mineral 25: 683-693

McDonough WF, Sun SS (1995) The composition of the Earth. Chem Geol 120: 223-253

McGetchin TR, Besancon JR (1973) Carbonate inclusions in mantle-derived pyropes. Earth Planet Sci Lett 18: 408-410

McGetchin TR, Silver LT (1970) Compositional relations in minerals from kimberlite and related rocks in the Moses Rock dike, San Juan County, Utah. Am Mineral 55: 1738-1771

McGetchin TR, Silver LT (1972) A crustal-upper mantle model for the Colorado Plateau based on observations of crystalline rock fragments in the Moses Rock dike. J Geophys Res 77: 70227037

McGetchin TR, Silver LT, Chodos AA (1970) Titanoclinohumite: a possible mineralogical site for water in the upper mantle. J Geophys Res 75: 255-259

McHale AE, Roth RS (1986) Low-temperature phase relationships in the system $\mathrm{ZrO}_{2}-\mathrm{TiO}_{2}$. J Am Ceram Soc 69: 827-832

Mercier J-CC (1976) Single-pyroxene geothermometry and geobarometry. Am Mineral 61: 603-615

Mitchell RH (1994) Accessory rare earth, strontium, barium and zirconium minerals in the Benfontein and Wesselton calcite kimberlites, South Africa. In: Meyer HOA, Leonardos OH (eds) Kimberlites, related rocks and mantle xenoliths. CPRM Spec Publ 1/B, Brasilia, pp 115-128

O'Hara MJ, Mercy ELR (1966) Eclogite, peridotite and pyrope from Navajo Country, Arizona and New Mexico. Am Mineral 51: $336-352$

O'Neill HStC, Wood BJ (1979) An empirical study of Fe-Mg partitioning between olivine and garnet and its calibration as a geothermometer. Contrib Mineral Petrol 70: 59-70

Roden MF (1981) Origin of coexisting minette and ultramafic breccia, Navajo Volcanic Field. Contrib Mineral Petrol 77: 195-206

Roden MF, Smith D, Murthy VR (1990) Chemical constraints on lithosphere composition and evolution beneath the Colorado Plateau. J Geophys Res 95: 2811-2831

Rouse RC, Peacor DR (1968) The relationship between senaite, magnetoplumbite and davidite. Am Mineral 53: 869-879

Ryerson FJ, Watson EB (1987) Rutile saturation in magmas: implications for Ti-Nb-Ta depletion in island arc basalts. Earth Planet Sci Lett 86: 225-239

Schiano P, Clocchiatti R (1994) Worldwide occurrence of silicarich melts in sub-continental and sub-oceanic mantle minerals. Nature 368: 621-624

Schiano P, Clocchiatti R, Shimizu N, Weis D, Mattielli N (1994) Cogenetic silica-rich and carbonate-rich melts trapped in mantle minerals in Kerguelen ultramafic xenoliths: implications for metasomatism in the oceanic upper mantle. Earth Planet Sci Lett 123: $167-178$

Schiano P, Clocchiatti R, Shimizu N, Maury RC, Jochum KP, Hofmann AW (1995) Hydrous, silica-rich melts in the sub-arc mantle and their relationship with erupted arc lavas. Nature 377: 595-600

Schulze DJ (1990) Silicate-bearing rutile-dominated nodules from South Africa kimberlites: metasomatized cumulates. Am Mineral 75: 97-104

Smith D (1979) Hydrous minerals and carbonates in peridotitic inclusions from the Green Knobs and Buell Park kimberlitic diatremes on the Colorado Plateau. In: Boyd FR, Meyer HOA (eds) The mantle sample: inclusions in kimberlites and other volcanics. Am Geophys Union, Washington, pp 345-356

Smith D (1987) Genesis of carbonate in pyrope from ultramafic diatremes on the Colorado Plateau, southwestern United States. Contrib Mineral Petrol 97: 389-396

Smith D (1995) Chlorite-rich ultramafic reaction zones in Colorado Plateau xenoliths: recorders of sub-Moho hydration. Contrib Mineral Petrol 121: 185-200

Smith D, Barron BR (1991) Pyroxene-garnet equilibration during cooling in the mantle. Am Mineral 76: 1950-1963

Smith D, Levy S (1976) Petrology of the Green Knobs diatreme and implications for the upper mantle below the Colorado Plateau. Earth Planet Sci Lett 29: 107-125

Smith D, Wilson CR (1985) Garnet-olivine equilibration during cooling in the mantle. Am Mineral 70: 30-39

Varlamov DA, Garanin VK, Kostrovitskiy SI (1996) Exotic hightitanium minerals as inclusions in garnets from lower crustal and mantle xenoliths. Trans Russ Acad Sci Earth Sci 345A: 352-355

Vlassopoulos M, Rossman GR, Haggerty SE (1993) Coupled substitution of $\mathrm{H}$ and minor elements in rutile and the implications of high $\mathrm{OH}$ contents in $\mathrm{Nb}$ - and $\mathrm{Cr}$-rich rutile from the upper mantle. Am Mineral 78: 1181-1191

Wang L, Zhang Y, Essene EJ (1996) Diffusion of the hydrous component in pyrope. Am Mineral 81: 706-718

Wang L, Rouse RC, Essene EJ, Peacor DR, Zhang Y (1998) Carmichaelite, a new hydroxyl-bearing titanate from the upper mantle. Eos Trans Am Geophys Union Spring Meet Suppl 79(17): S161

Watson KD (1967) Kimberlite pipes of northeastern Arizona. In: Wyllie PJ (ed) Ultramafic and related rocks. J Wiley and Sons, New York, pp 261-269

Webb SAC, Wood BJ (1986) Spinel-pyroxene-garnet relationships and their dependence on $\mathrm{Cr} / \mathrm{Al}$ ratio. Contrib Mineral Petrol 92: 471-480

Willgallis A, Siegmann E, Hettiaratchi T (1983) Srilankite: a new Zr-Ti-oxide mineral. Neues Jahrb Mineral Monatsh 1983: 151157

Willgallis A, Brauer R, Buhl J-C (1987) Investigation regarding the synthesis of srilankite $\left(\mathrm{Zr}_{0.33} \mathrm{Ti}_{0.67}\right) \mathrm{O}_{2}$. Neues Jahrb Mineral Monatsh 1987: 129-135

Wyllie PJ (1979) Magmas and volatile components. Am Mineral 64: $469-500$

Wyllie PJ (1987) Metasomatism and fluid generation in mantle xenoliths. In: Nixon PH (ed) Mantle xenoliths. J Wiley and Sons, Chichester, pp 609-621

Zhang Y (1998) Mechanical and phase equilibria in inclusion-host systems. Earth Planet Sci Lett 157: 209-222

Zhao D, Essene EJ, Zhang Y, Pell JA (1998) Mantle xenoliths from the Nikos kimberlites on Somerset Island and the Zulu kimberlites on Brodeur Peninsula, Baffin Island, Canada. In: Extended Abstr, 7th Int Kimberlite Conf, Cape Town, S Afr, pp 998-1000

Zhou J, Yang G, Zhang J (1984) Mathiasite in a kimberlite from China. Acta Mineral Sinica 9: 193-200 